Dokuz. Eylül Üniversitesi

İlahiyat Fakeültesi Dergisi

2015/1, Sayn 41, ss. 213-242.

\title{
TEFSÎRDE KİTAB-I MUKADDESİN TAHRÎFİ MESELESİ: II (Tahrîf Kelimesinin Müradifleri Bağlamında)
}

Ferruh KAHRAMAN*

\section{ÖZET}

Bu çalışma "Tefsîrde Kitab-1 Mukaddesin Tahrîfi Meselesi” I adlı makaleyi tamamlar niteliktedir. Her iki makale de Kutsal kitapların tahrifini ele almaktadır. Fakat ilk makale, tahrîfin mahiyet ve şekli daha iyi anlaşılsın diye sadece tahrif kelimesi çerçevesinde sınırlandırılmıştır. Bu nedenle ilk makalede tahrîfin Kur'ân-1 Kerîm'de geçen müradiflerine değinilmemiștir. Kur'ân-1 Kerîm'de tahrîf ve mahiyeti mezkur kelime dışında özellikle "tebdîl", "kitmân”, "leyy", "lebs" ve "nisyân” sözcükleri ile de ifade edilmiștir. Bu kelimelerin geçtiği âyetler bütüncül olarak değerlendirildiğinde Yâhûdî ve Hiristiyanların kendilerine indirilen vahyi değişik sûretlerde tahrîf ettiği sonucuna ulaşılmıştır. "Tefsîrde Kitab-1 Mukaddesin Tahrîfi Meselesi” I (Tahrîf Kelimesi Bağlamında) adlı ilk makale, onların kutsal kitaplarının aslını koruyamamalarına işaret ederken; bu makale ile "tebdîl", "kitmân”, "leyy", "lebs" ve "nisyân” kelimelerinin anlamından yola çıkarak farklı tahrîf çeşitlerine dikkat çekilmiştir.

Anahtar kelimeler: Tefsîr, tahrîf, problem, lafiz, manâ

THE ISSUE OF CORRUPTION OF HOLY BOOKS IN TAFSEER: II

(In the Context of Synonyms and the Ways of the Word of Corruption)

\section{ABSTRACT}

The present study is a complement to the former article. Both articles point out the corruption of the Sacred texts. However the first one addresses the word of corruption only, not the synonyms of the word. It must be known that tebdîl, kitmân, leyy, lebs and nisyân which are the synonyms of the word of corruption are used in Quran. Speaking of the present study, the synonym words are examined in the context of the verses related to the subject. If the verses are widely examined, it seems Christians and Jews corrupted the verses revealed to them in different ways. The former article, The Issue of Corruption in Quranic Exegesis (In the Context of the Word of Corruption), highlights that Christians and Jews could not protect the originality of their sacred texts, the present study addresses different ways of corruption in the context of the semantic meanings of the words: tebdîl, kitmân, leyy, lebs and nisyân

Key words: Exegesis, corruption, problem, text, meaning

* Yrd. Doç. Dr., Dokuz Eylül Üniversitesi, İlahiyat Fakültesi, Arap Dili ve Belağatı ABD Öğretim Üyesi. 


\section{GİRIŞ̧}

Kur'ân'da Ehl-i kitabın Tevrât ve İncîl gibi kutsal kitapları tahrîf ettikleri (müntesipleri bağlamında) bildirilir. Ancak Kur'ân'da kutsal kitapların tahrîfinden ziyade; asıl vurgu, kadîm dinlerin müntesiplerinin din ve peygamberlerine karşı gayr-i ciddi tutumları, dindeki bazı kelimeleri değiştirmeleri ve bazı hükümleri menfaatlerine göre yorumlamaları şeklindedir. Yani Kur'ân diğer kitaplar şöyle şöyle tahrîf edildi ve bozuldu demez. Bunun yerine onlar şöyle bir kelimenin yerine bașka bir kelimeyi koydular veya kitaptaki bir hükmü bile bile amacı istikametinde uyguladılar demektedir. Kadìm kutsal kitaplar konusundaki en büyük çımaz daha çok şahıs merkezli olan tahrîfin metin merkezli olarak anlaşılmasıdır. Kur'ân'da tahrîf kelimesi muhatap merkezli değil de metin merkezli ele alındığı için tahrîfin şekli ile ilgili farklı görüşler ortaya çıkmıştır. Tahrîf üzerine yapılan çalışmalarda bu önemli fark (metin ve onu anlayan) bazen göz ardı edilmiş, kadîm milletlerin bir dua ve selam karşısında söyledikleri bazı kelimeler bile metin veya manâ merkezli tahrîfe delil gösterilmiştir. ${ }^{1}$ Bazı müellifler de meseleye sadece belli âyetler çerçevesinde yaklaştığı için metin tahrîfini ya inkar etmişler, ya da sınırlı sayıda örnek vermekle yetinmişlerdir. Diğer önemli bir mesele de tahrîfin tefsîrde dinler tarihindeki kadar ele alınmamasıdır.

Yukarıda sayılan bazı olumsuzluklar ve eksiklikler göz önünde bulundurularak çalışmada tefsîrin yanı sıra bizzat kutsal kitapların kendisine müracaat edilmiş, bunun yanında âyetlerin daha geniş perdeden değerlendirilebilmesi için dinler tarihi ve kelam gibi ilimlerin de verilerinden yararlanmaya çalışlımıștır. Âyet âyet ve müfessirlerin görüşlerine müracaat edilerek yapılan bu çalışmada, kelimeler arasındaki benzerlik ve farklar ortaya konmuştur. Bu çalışma sayesinde okuyucu tahrîf kelimesinin müradiflerini geniş açıklamalarıyla birlikte bulabilmektedir.

Tefsîrde tahrîf, açık bir şekilde bizzat tahrîf kelimesiyle ifade edildiği gibi eş anlamlıları olan "tebdîl", "kitmân", "leyy", "lebs" ve "nisyân" lafızlarıyla da ifade edilir. Bu lafizlar, müntesipleri tarafindan kadîm kitapların nasıl amacı dışında yorumladıklarını anlatır. Tahrîf kelimesi bir lafız ve anlamı bozmayı ifade ederken mezkûr kelimeler de bu bozulmanın şeklini göstererek Müslümanlara başlıca iki ders verir. Bu derslerden ilki kadîm toplumlardan bazılarının dine lakayt tavrını bize bildirerek, bu tip insanlarla her an karşılaşmanın muhtemel olduğu; ikincisi de Müslümanların dini konularda çok titiz olup onların düştükleri bu duruma düşmemeleridir.

Daha önceki makalede sadece tahrîf kelimesi ele alındığı için burada müradiflerinin/eş anlamlılarının sarih olarak geçtiği âyetler bağlamında

1 Bkz. Bakara 2/58 ve Taberî, Câmiü'l-beyân, Müessesetü’r-risâle, Beyrut 2000, II, 112, 113. 
değerlendirme yapılmıştır. Değerlendirmelerde de gerek görüldüğünde ilk dönemden itibaren önemli kabul edilen farklı tarih ve coğrafyaya ait müfessirlere müracaat edilmiștir. Ancak son dönem Türk müfessirlerine ise daha fazla yer verilmiştir. Böylece son dönem Türk müfessirlerin görüşleri merkeze alınmakla beraber belli bir dönemle sınırlandırılmamasındaki gaye, tarih boyunca tahrîfin nasıl algilandığı ve ilk dönemle son dönem arasındaki farkların olup olmadığının tespit edilmesidir.

Üç bölümden oluşan bu makalenin birinci bölümünde tabrîfin müradifleri olan tebdîl, kıtmân, leyy, lebs ve nisyân gibi kelimelerin Arapçada hangi anlamlara geldiği ifade edilmiş, ikinci bölümde tefsîrde Kutsal kitapların bozulmasının şekli ile ilgili yaklaşımlar ortaya konmuş, son bölümde ise tahrîfle ilgili âyetlerin yorumları özellikle son dönem Türk müfessirlerine göre değerlendirilmiştir.

\section{A. TAHRÎFE ANLAM YAKINLIĞI OLAN KELİMELER} (Tebdîl, Kitmân, Leyy, Lebs ve Nisyân)

Kur'ân'da tahrîfle yakın anlamlı kullanılan kelimelerin başında "tebdîl", "kitmân", "leyy", "lebs" ve "nisyân" gelmektedir. Tahrîfin daha iyi anlaşılması için bu bölümde onun müradiflerine yer verilmiştir.

\section{Tebdîl}

Tebdîl, Arapça beddele/بدَّل fiilinin mastarıdır. Tebdîl, bir şeyin kendi halini, yerini başka bir şeyle değiştirmektir. İsfehânî, (ö. 502/1109) tebdîli karşıllğı olmayacak şekilde mutlak olarak değiştirmek şeklinde açıklamıştır. ${ }^{2}$ İbn Manzûr (ö. 711/1311) da, Bir şeyi tebdîl etmenin onu bozmak anlamlarına geldiğini ifade etmiş ve "vallahi" lafżnın "tellahi” lafzına dönüştürülmesini örnek vermiştir. Her ne kadar iki kelime yemin anlamina gelse de kelimenin başındaki $\mathrm{g} /$ vâv harfinin $ت$ /tâ harfine dönüştürülmesini tebdîl olarak açıklar.

Kısaca tebdîl bir şeyi, tam olarak bedeli olmayacak bir şeyle değiştirmektir. ${ }^{3}$ Lügatçılar tebdîlin değiştirmek anlamında olduğu konusunda birleşmektedirler. Ancak bu değişiklik kimilerine göre tamamen kelimenin aslının bozulmasından; kimilerine göre ise ufak değişikliklerden ibarettir. Tahrîf manâsında kullanılan tebdîl, Kur'ân'da üç yerde Hz. Mûsâ dönemi İsrailoğullarından bahsedilirken zikredilir. ${ }^{4} \mathrm{Bu}$ da tebdîl olayının $\mathrm{Hz}$. Mûsâ döneminde ayrı bir yere haiz olduğuna bir delildir.

2 İsfehânî, İsfehânî, Ragıb, Müfredât, Safvân Adnan, Dâru'l-kalem-ed-Dâru'ş-şamiyye, DımeşkBeyrut 1412, I, 111.

3 İbn Manzûr, Lisânü'l-Arab, Dâru sâdır, Beyrut 1414, IX, 48, 49.

4 Bakara 2/59, 211; A’râf 7/162. 


\section{Kitmân}

Kitmân, Arapça keteme/ت S filinin mastarıdır. "ilan etme veya bildirme"nin zıddır. "Sözü örtmek, fazilet ve nimetleri gizlemek" anlamlarında kullanilır. ${ }^{5}$ Bir şeyi gizlemek, saklamak anlamına gelir. ${ }^{6}$ Kitmân kelimesi; Kur'ân'da yedi yerde Medine Yahûdîleri ile Hiristiyanlara hitap eden âyetlerde geçmektedir. ${ }^{7}$ Nasıl ki tebdîl daha çok Hz. Mûsâ dönemi Yahûdîlerini hatırlatıyorsa, bu kelime de Hz. Peygamber dönemi Yahûdîlerinin karakterini yansıtmaktadır. Hz. Peygamber döneminde Yahûdîlerin yaptığı işlem tahrîf olsa da tahrîfin boyutu kitmân şeklindedir.

\section{Leyy}

Leyy, levâ/ fiilinin mastarıdır. "Bükmek, kıvırmak, eğmek; saptırmak, çevirmek" anlamlarına gelmektedir. İsfenânî'ye göre leyy, ipi eğmek, bükmek; dili eğip bükmek anlamındadır. Yalan sözden kinayedir. Yalan sözler uydurmak anlamına da gelir. ${ }^{8}$ İbn Manzûr da İsfenânîyle aynı doğrultuda leyy'i, ipi eğmek bükmek; katlamak, bükmek, germek, gerginleștirmek manâsında açılamıştır. ' Leyy kelimesi; Ehl-i kitabın, kutsal kitaplarını tahrîflerinin boyutunu açılar mahiyette Kur'an'da, iki yerde geçmektedir. ${ }^{10}$ Leyy kelimesi Hz. Peygamber dönemi Yahûdîlerinin Müslümanların zihnini bulandırmak ve kitaplarında işlerine gelmeyen yerleri gizleyemedikleri için dilleriyle eğip bükmelerini anlatır. Leyy kelimesi de Medine Yahûdîleri için kullanılır.

\section{Lebs}

Lebs, lebese/ب fiilinin mastarıdır. "Karıştırmak anlamına" gelmektedir. ${ }^{11}$ Lebs kelimesi; iki yerde Kur'ân'da Ehl-i kitaba hitaben geçmektedir. ${ }^{12}$ Lebs kelimesi de Medine Yahûdîlerini anlatır durumdadır.

\section{Nisyân}

Nisyân, nesiye/ fiilinin mastandır. "Unutmak, aklından gitmek" anlamındadır. Kişinin, emanet edilen şeyin muhafazasını kalbinin zayıflı̆ı̆ından veya gafletten dolay1 unutmasi ya da ihanet etmesi ve kasden terketmesidir.

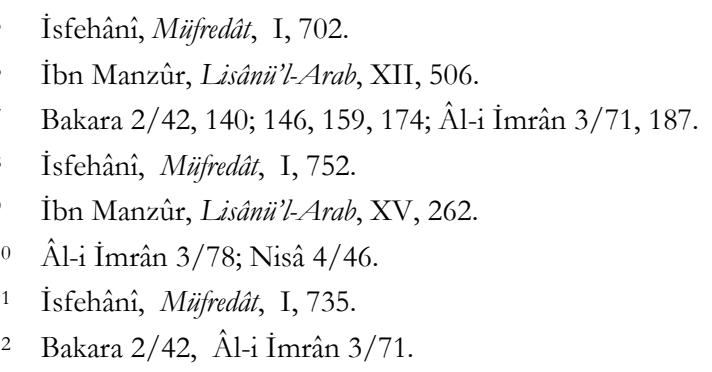


Dolayısyla "kişinin bir şeyi hatırlamaktan uzak olup unutması halidir". ${ }^{13}$ Nisyân kelimesi; Hz. Mûsâ dönemi Yahûdîleri, Medine Yahûdîleri ve Hiristiyanlarla ilgili olarak Kur'ân'da üç yerde geçmektedir. ${ }^{14}$ Dolayısıyla nisyân kelimesi tebdîl, leyy ve lebs kelimelerinden farklı olarak hem belli bir dönemle hem de belli bir milletle sınırlandırılmamıştır.

\section{B. TEFSIRDE TAHRÎFİN ŞEKLİ İLE İLGİLI} YAKLAŞIMLAR (Tebdîl, Kitmân, Leyy, Lebs ve Nisyân)

Kur'ân-1 Kerîm'de; Ehl-i kitabın kutsal kitaplarına olumsuz yaklaşımları açıç̧a ifade edilmiştir. Dolayısıyla bu konuda tefsîrde aksi görüş bulunmaz. Ancak tahrîfin mâhiyeti konusunda farklı görüşler vardır. Tefsîrin ilk dönemlerinden bu yana mezkûr konu lafız ve manâ bağlamında ele alınmıştır. Dolayısıyla değişik görüşlerin ve ihtilafin oluşmasına yol açan husus, tahrîfin lafızla mı yoksa manâ ile mi yoksa her ikisiyle mi olduğudur. Kimi alimlere göre bu konu Kur'ân'da açı değildir. Tahrîf; tefsîrlerde yazılı metnin doğrudan doğruya değiştirilmesi, metinden bazı kısımların çıarıllması veya metne ilaveler yapilması, metin doğru olduğu halde okunurken keyfi olarak değiştirilmesi ya da doğru olan metnin yanlış tefsîr edilmesi gibi değişik şekillerde olabilir. ${ }^{15}$ Bundan dolayı da tahrîf kısaca dört şekilde meydana gelir. ${ }^{16}$ Ilki bir metnin lafzen tahrîf

13 İsfehânî, Müfredât, I, 803.

14 Mâide 5/13, 14; A`râf 7/53.

15 Mâtürîdî, Ebû Mansur, Te'vîlâtü ebli's-sünne, Müessesetü'r-risâle, Beyrut 2004, I, 285; Râzî, Fahruddîn, Mefâtîhu'l-ğayb, Dâru ihyâi'l-türâsi'l-Arabî, Beyrut 1420, III, 144; Zemahşerî, Ebû Kasım Mahmûd b. Ömer, el-Kesșấf an bakâik ğavâmidit-tenzîl ve'l-uyûni'l-avâni'l fì vücûbi't-te'vîl, Dâru ihyâi't-türâsi'l-Arabî, Beyrut 1997, I, 548, 549; I, 666; Elmalılı, Hak Dini Kur'ân Dili, I, 327; III, 246.

16 Konuyla ilgili çalışma yapan araştırmacılar bunu ikili ve üçlü bir yapı içerisinde ele almışlardır. Tartışmalar için bkz. Goldziher, Ignaz, "Ehl-i Kitaba Karşı İslâm Polemiği I" çev. Cihad Tunç, Ankara İlabiyat Fakültesi İslâm İlimleri Enstitüsü Dergisi, sy. 4, Ankara 1980, s. 151-170; Goldziher, Ignaz, "Ehl-i Kitaba Karşı İslâm Polemiği II" çev. Cihad Tunç, Ankara İlabijat Fakültesi İslâm İlimleri Enstitüsü Dergisi, sy. 5, Ankara 1982, s. 249- 278; Adam, Baki, Yahudi Kaynaklarna Göre Tevrât, Pınar Yay., İstanbul 2001, s. 208-232; Adam, Baki, “Kur'ân'ın Anlaşılmasında Tevrât'ın Rolü”, İslâmî Araştırmalar Dergisi, c. 9, sy. 1- 4, Ankara 1996, s. $167-$ 176; Adam, Baki, "Tevrât'ın Tahrîfi Meselesine Müslüman ve Yahudi Cephesinden Bir Bakış", Ankara İlabiyat Fakültesi Dergisi, sy. 36, Ankara 1997, s. 359-404; Gökkır, Necmeddin, "Kur’ân-1 Kerîm Açısından İlahî Kitapların Tahrîfi Meselesi”, İstanbul Üniversitesi İlabiyat Fakëlltesi Dergisi, sy. 2, İstanbul 2000, s. 221-256; Gaudeul, J.M. - R. Caspar, "Kitab-1 Mukaddes'in Tahrîfi Konusunda Klasik İslami Kaynakların Yaklaşımı”, çev. Ali Erbaș, Sakarya Üniversitesi İlabiyat Fakültesi Dergisi, sy. 7, Sakarya 2003, s. 131-167; Biçer, Ramazan, İslâm Kelâmcilarna Göre İncîl, Gelenek Yay., İstanbul 2004, s. 87 ve devamı. Tarakçı, Muhammed, "Tevrât ve İncîl'in Tahrîfi ile İlgili Kur'ân Âyetlerinin Anlaşılması Sorunu” Usûul Dergisi, sy. 2, Adapazarı, 2004, s. 33-53; Yıldırım, Arif, "Kelamî Açıdan Tevrât ve İncîlde Tahrîf Meselesi”, Atatürk Üniversitesi İlabiyat Fakültesi Dergisi, sy. 26, Erzurum 2006, s. 11-26; Yavuz, Salih Sabri-Yeniçağ, İbrahim, "Müslüman-Hıristiyan Polemiği Açısından Tahrîf", Milel ve Nibal, cilt 6/sy 1, y. y. Nisan 2006, s. 305-344. 
edildiğidir. ${ }^{17}$ İkincisi ise lafzen değil de bizzat metnin yorumlanması ve anlaşılması aşamasında gerçekleşen tahrîftir. ${ }^{18}$ Bir diğer görüş olan üçüncüsü de her ikisini kapsayacak şekilde hem lafiz hem de manâda olan tahrîftir ${ }^{19}$. Dördüncüsü ise yine lafız ve manâda olmak üzere cüzîdir ${ }^{20}$. Diğeriyle cüzî ve küllî olma noktasında ayrılmaktadır. Tahrîfin meydana gelme şekli ise bize göre genel olarak beş şekildedir. Bu beș şekil ise, Kur'ân'da tahrîf anlamında kullanılan kelimelerle ifade edilmiştir. Tahrîf ise bunların üzerinde genel/amm bir kavram olup hepsini kuşatmaktadır. Dolayısıyla tahrîfin nasıl meydana geldiğini anlamak için onun müradiflerine bakmak faydalı olacaktır.

\section{TAHRÎFE ANLAM YAKINLIĞI OLAN KELIMMELERİN}

YORUMU (Tebdîl, Kitmân, Leyy, Lebs ve Nisyân)

Tahrîfe Anlam Yakınlı̆̆ı Olan Kelimelerin başında tebdîl, kitmân, leyy, lebs ve nisyân gibi kelimeler gelmektedir. Bunlar bazı müfessirler tarafindan tahrîfle eş anlamlı olarak değerlendirilse de aslında bunlar tahrîfin nasıl meydana geldiğini açıklayan kelimelerdir. Tahrîf mutlak olarak bir şeyin aslının değiştirilmesi, ${ }^{21}$ bozulması, tebdîl ve tağyîr edilmesi için kullanılan şemsiye bir kavramdır. Her ne kadar "tebdîl", "kitmân", "leyy", "lebs" ve "nisyân" kelimeleri bazen tahrîf veya birbiri anlamında kullanılsa da bunların kendilerine göre müstakil anlamları vardır. Bu kısa açıklamadan sonra şimdi de müfessirlerin ilgili âyetler bağlamında mezkûr kelimeleri nasıl açıkladıklarına yer verelim.

\section{Tebdîl Kelimesi Etrafinda Yapılan Yorumlar}

Tebdîl kelimesi Kur'ân-1 Kerîm'de İsrailoğulları'nın gerek yazılı gerekse sözlü, bazı hüküm ve ibareleri için toplam üç yerde kullanılır. Bunlardan ikisi Bakara sûresinde (59 ve 211. âyetler) birisi de A'râf (162. âyet) sûresinde Hz. Mûsâ dönemi İsrailoğulları için kullanılır.

17 İbn Hazm, Kitâbü'l-fasl, Matbaatü'l-Edebiyye, Kahire 1902, II, 18-21; Cüveynî, Şifâül-ğgalil, thk. Michel Allard, Dâru'l-meşrık, Beyrut 1968.

18 Makrîzî, Ahmed b. Ali, Hıtat el-Makrîzî, y.y. Kahire 1270, s. 475; Dihlevî, Şah Veliyyullah, Fevzüi'l-kebîr, çev. Mehmet Sofuoğlu, Çağnı Yay., İstanbul 1980, s. 13; Elmalılı, Hak Dini Kur'ân Dili, Azim Dağıtım, İstanbul t.s., I, 327; III, 246.

19 Bkz. Ebû Mansur, Te'vîlâtü ebli's-sünne, I, 285; Râzî, Mefâtîhu'l-ğayb, III, 144; Zemahşerî, elKeşsâf, I, 548, 549; I, 666; Elmalılı, Hak Dini Kur'ân Dili, I, 327; III, 246.

20 Bkz. İbn Sina, er-Risâletü'l-edhaviyye fi'l-meâd, y.y., 1969, s. 58, 59. Ancak İbn Sina burada kismî bir anlam tahrîfinden söz etmektedir.

20 İbn Haldun, Kitâbü'l-iber, Dâru'l-kitâbi'l-Lübnânî, Beyrut 1956, II, 10, 11.

21 İsfehânî, Müfredât, I, 228; İbn Manzûr, Lisânü'l-Arab, IX, 43. 


\section{Bakara 2/59:}

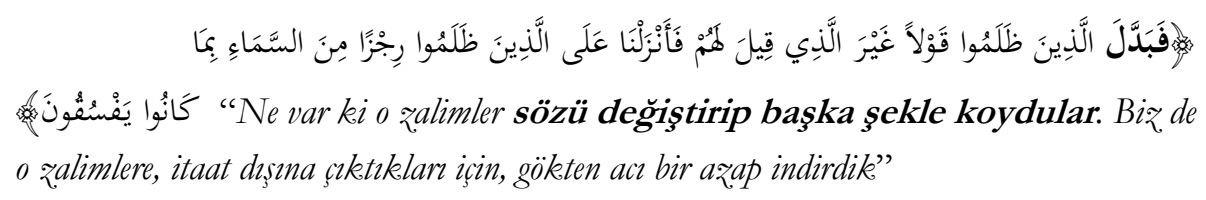

Beydâvî’nin (ö. 681/1282) görüşüne göre, Yâhûdîlerin kurtuluşlannna sebep olacak "günahımızı affet" manâsında hitta kelimesinin yerine hinta-i bamra/kırmı ̨ buğday demeleri helak olmalarına sebep olmuştur. Bu tebdîl sebebiyle zalim sıfatına layık olduklarından Yüce Allah iki defa onları zalim olarak açıklamıştır.22 Ebussuud Efendi'ye (ö. 981/1574) göre; Yahûdîlerin fıskları evvel ve ahir devam ettiğine işaret için, fısklarını açıklamak için mazi ve muzari sigaları kullanılmıştır. ${ }^{23} \mathrm{Bu}$ ilginç yorum, onların zalimliklerine ahir zamana kadar devam edeceğine işaret eder. Elmalılı bu âyeti diğer müfessirler gibi bir önceki âyete bağlı olarak orada geçen hıtta kelimesiyle açıklamaktadır. Zira Yüce Allah İsrailoğulları'na Beyt-i Makdis'e girmelerini ve orada diledikleri yerde, diledikleri nimetlerden yemelerini söylemiştir. Ancak o şehre, şükür secdesi yaparak ve hatalarının affina sebep olacak hitta kelimesini zikrederek girmelerini emretmiş̧ir. Fakat o zalimler, kapıdan girer girmez, Allah'ın emrini değiştirmeye ve bozmaya, hitta kelimesini alaya alarak onun yerine kırmızı buğday anlamında başka bir söz söylemeye kalkıştılar. Bunun neticesinde de Allah'ın azabına müstehak oldukları belirtilmiştir. Ayrıca Elmalılı'ya göre, bunu yapanlar ve bu azaba uğratılanlar Hz. Mûsâ kavminden bir gruptur. Çünkü âyette 'o zulmedenler değiştirdiler' sözü içlerinden bir kısmı anlamına gelmektedir. ${ }^{24}$

Vehbi Efendi (ö. 1949) de Beydâvî'den etkilenerek ve onunla aynı görüșü benimseyerek âyeti açıklamıștır. Ona göre âyet; İsrailoğulları'nın 'hıtta' kelimesiyle istiğfar etmeleri emrine muhalefet ettiklerini ve bu muhalefet neticesinde helak olduklarını bildirmektedir. Yüce Allah, İsrailoğulları'na "günahımızı affet" manâsında hıtta demelerini emretmiştir. Fakat onlar bu emri hafife ve alaya alarak henta-i hamra yani kırmı z buğday isteriz dediler. ${ }^{25}$ Ayrica Vehbi Efendi, tebdîl konusunda da açıklamada bulunur ve şöyle der: Yüce Allah'ın âyetlerini, manâ yönünden uygun olan başka bir lafza tebdîl caiz ise de, tebdîl olmaksızın aynı lafızla eda etmenin daha uygun olduğuna âyet delalet etmektedir. Bununla beraber, manâya uymayan bir lafza tebdîl etmenin caiz olmadığına ve böyle bir tebdîle cüret eden kimsenin zalim ve fasık olduğuna

22 Beydâvî, Nâsıruddîn Ebû Saîd, Envâru't-tenzîl', Dâru ihyâi't-türâsi'l-Arabî, Beyrut 1418, I, 82.

23 Ebususud Efendi, İrşâdü akli's-selîm, Dâru ihyâi't-türâsi'l-Arabî, Beyrut ts., I, 59.

24 Elmalıli, Hak. Dini Kur'ân Dili, I, 305.

25 Vehbi Efendi, Hulâsatü'l-beyân, I, 135. 
işaret etmektedir. ${ }^{26}$ Bilmen (ö. 1971) İsrailoğulları'ndan zulümkar olan şahıslar hıtta kelimesini başka bir söze çevirdiler. Hıtta yerine hınta-i hamra/kırmızı buğday gibi bir söz söyleyerek alaycı bir tavırda bulundular. Ve âyetin devamında Yüce Allah, ilahi emre muhalefetle nefislerine zulmettiklerinden dolayı onları, layık olan cezaya kavuşturduğunu belirtir. ${ }^{27} \mathrm{Bu}$ âyetin tefsîrinde Bilmen'in Vehbi Efendi’yle aynı görüşte olduğu görülür.

\title{
Bakara 2/211:
}

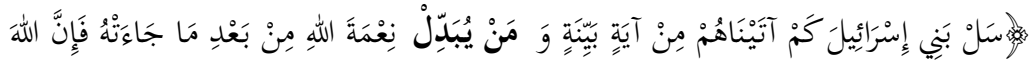 \\ شَ' israiloğullarna sor, onlara nice açl belgeler verdik! Her kim, Allah'in
}

kendisine lütfetmiş olduğu nimeti değiştiritse, iyice bilsin ki Allah'ın cezası pek siddetlidir".

Yüce Allah, Hz. Peygamber'den, İsrâiloğulları'na ne kadar mucize verdiklerini onlara sormasını istemektedir. Onların bu mucizeleri inkar edip azaba müstehak olduklarını da ardından bildirmektedir. Bir kimse hidayetine sebep olan nimet kendisine geldikten sonra Allah'in o nimetini tahrîf veya maksadına uymayacak şekilde tevil etmek suretiyle dalalete tebdîl ederse, Yüce Allah'ın azabına müstehak olur. Çünkü nimetin asıl işlevi hidayeti sağlamaktır bunun önemini anlamayıp nankörlük eden kimse bu davranışılla imanı küfre, hidayeti dalalete, mutluluğu da azaba çevirmiş olur. ${ }^{28}$ Elmalılı bu âyete fazla bir açılama getirmemiştir. Sadece "onlar, bu âyetleri dinledikleri zaman ne oldular, dinlemeyip durumlarını değiştirdikleri zaman ne oldular? Allah'ın nimetini (bunlar gibi) her kim değiştirir, bozar da zarar ve bozgunculuk peşinde koşarsa Allah'ın onlara cezası da herhalde pek şiddetlidir" şeklinde bir açılamayla yetinmiştir. ${ }^{29} \mathrm{O}$, âyet kelimesinden kastın ne olduğuna da değinmemiştir. Ancak kanaatimizce Elmalıll'ya göre, âyet, ilahi kitabın âyetleridir. Çünkü âyetleri dinlediklerini ve sonra onları değiştirdiklerini vurgulamaktadır. Elmalılı'nın âyeti mucize olarak değil de normal âyet olarak açıkladığı kanısındayız. Vehbi Efendi, âyette geçen İsrâiloğulları'na verilen âyetten kastın; Hz. Mûsầya verilen âsâ ve denizin yol alması gibi mucizeler olduğunu açılar. ${ }^{30} \mathrm{Bu}$ bilgiler ilk dönemlerden beri rivâî tefsirlerde de yer almaktadır. ${ }^{31}$ İlginç olan bu mucizelerin değiştirilmesinin nasıl olacağıdır. Âyet kelimesi, sözü geçen mucizeleri kapsasa da, aynı zamanda İsrâiloğulları'na indirilen Tevrât'’n âyetlerini de içine alan bir

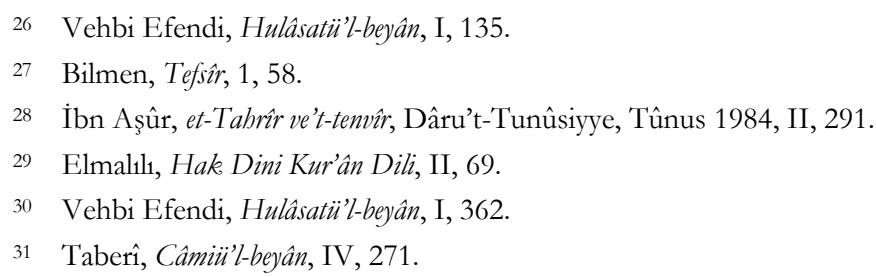


yoruma açıktır kanaatindeyiz. Çünkü Allah'ın kullarına gönderdiği nimetlerin en büyügü O'nun kitabıdır ki bu nimetin tebdîl edilmesi Kitab'ın tahrîf edilmesi manâsındadır. Böyle bir manâ da çok açık olmakla birlikte Vehbi Efendi’nin âyete bu şekilde bir yorum yapmadığını görmekteyiz. Sonuç olarak, Vehbi Efendi; İsrâiloğulları'na, hakka delalet eden ve hidayete vesile olan birçok âyet verildiğini, bu âyetlerin ümmet için nimet olduğunu ve bu nimeti maksadina uymayacak şekilde kullanarak tebdîl edenlerin azap göreceklerini belirtir. Bu açılama da âyetin İsrâiloğulları'nın ilahi kitaplarını tebdîl ettikleri yorumunu destekler mahiyettedir. Bilmen de âyette geçen âyet kelimesine Vehbi Efendi gibi mucize anlamını yüklemiş, ilahi kitabın âyetlerinin değiştirilmesi anlamını vermemiştir. Bilmen'e göre; İsrailoğullarına çok mucize verildiği ve bu mucizeleri gördükleri halde, onların yanlış yere gitmekten geri durmadıklanı âyette ifade edilmiştir. Sonuç olarak; bu nimetlere erdikten sonra onları değiştirmeye ve inkara cüret eden kimseler, Allah'ın azabıyla karşılaşacaklardır. ${ }^{32}$

\section{A'raf 7/162:

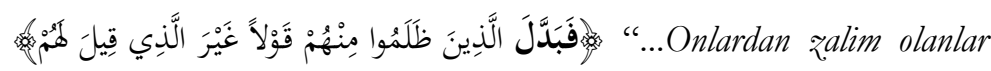 kendilerine söylenilen sözü söylenmeyen söze tebdîl ettiler..."}

Hz. Mûsâ İsrâiloğullarını vaad edilen topraklara götürürken onlardan bazılar1, kendilerine verilen bazı nimetlere nankörlük etmişler, onların bu nimetlere şükretmeleri gerekirken sözü değiştirip Allah'n emrine âsi gelmişlerdir. ${ }^{33}$ Elmallı bu âyette daha önce Bakara 59'da geçen yorumu yapmış, aynı şekilde hıtta kelimesini değiştirmek suretiyle İsrailoğulları'nın Tevrât'ı tahrîf ettiklerini belirtmiştir. Elmalilı, Tevrât'1 tahrîf edenlerin zalimler grubu olduğunu, zalimlerin o kavmin hepsi olmadığını, ancak çoğunluğunun böyle olduğunu da vurgulamıştır. ${ }^{34}$ Fakat bu zalimler grubunun Yahûdî bilginleri mi yoksa halktan bir grup mu olduğu konusunda bir açıklamada bulunmamıştır. Bakara 59. âyetin tefsîrinde olduğu gibi Vehbi Efendi, bu âyette de İsrailoğulları'nın, istiğfar etmeleri için söylemeleri emredilen hitta kelimesini lafzen ve manen tağyîr ettiklerini ve böylece zulüm yaptıklarını açıklamaktadır. Âyetin devamında da onların bu lafż tahrîf ederek ilahi emre muhalefet etmeleri sebebiyle helak oldukları belirtilir. ${ }^{83}$ Bilmen, bu âyetin açıklaması için Bakara 59'a bakılması gerektiğini söyler ve o âyetin yorumunu burada da dile getirir. Zaten âyet lafzen de diğer âyetle benzerlik arzetmektedir. Bilmen'e göre, burada

32 Bilmen, Tefsîr, I, 209.

33 Taberî, Câmiü'l-beyân, XIII, 179.

34 Elmalılı, Hak Dini Kur'ân Dili, IV, 156. 
da kastedilen; İsrailoğulları'nın kendilerine emredilen hıtta kelimesini alaya alarak başka bir söze çevirmeleridir." 35

Yukarıdaki âyetler ve müfessirlerin yorumları değerlendirildiğinde tebdîl kelimesinin her üçü de Hz. Mûsâ dönemi İsrâiloğullarının karakterini ortaya koymaktadır. Bu âyetler doğrudan kutsal kitabın tahrîfini ele almamakta, müntesiplerin dini bir emre karşı tavırlarını ortaya koymaktadır. Kısaca Yahûdîlerin Yüce Allah ve peygamberlerin emirlerine âsî geldiklerini ve onlarla alay ettiklerini bildirmektedir. Ancak bazı alimler bu örnekten yola çıkarak, bu tahrîflerin kitapların geneli için de düşünmekte ve bu âyetleri kutsal kitapların tahrîf olduğuna delil olarak göstermektedirler.

\section{Kitmân Kelimesi Etrafinda Yapılan Yorumlar}

Kitmân kelimesi; Kur'ân'da yedi yerde Medine Yahûdîleri ile Hiristiyanlara hitap eden âyetlerde geçmektedir. Kitmân, tebdîl kelimesinden daha farklı bir anlam içermektedir. Hz. Mûsâ döneminde Yâhûdiler alay mahiyetinde dinin bazı emir ifade eden kelimelerin talaffuzlarını değiştirerek söylemişler, Hz. Peygamber döneminde ise kitaplarında bazı hükümleri gizlemiş veya saklamışlardır. Kitmân bu ikincisine işaret eder. Kur'ân'da kitmân kelimesiyle yakın anlamda bazen ihvâ kelimesi de kullanılır. ${ }^{36}$

\section{Bakara 2/42:}

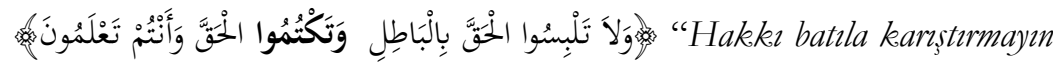 ve bakke bildiginiz halde saklamayın."}

Âyette geçen ve saklanan gerçek Kur'ân'’n Allah'ın kitabı olduğu, Hz. Peygamberin de beklenen son peygamber olduğudur. İnkarciların hak ile batılı birbirine karıştırarak gerçeği gizlememeleri istenmiştir. Âyette Yahûdîlerin kitaplarına ilave yaparak gerçeği gizlediklerine; ${ }^{37} \mathrm{~Hz}$. Peygamberin geleceğinin Tevrât'ta haber verildiği gerçeğini saklamalarına işaret eder. ${ }^{38}$ Hâzin'e (ö. 725/1324) göre âyette geçen hak, Resûlullah'ın vasıfları, batıl da bizzat sonradan yapılan ilaveler yani beşerî müdahalelerdir. ${ }^{39}$ Elmalılı'ya göre de bu âyet çok kapsamlı olup, sadece Hz. Peygamber'i yalanlamayı değil ilme ve amele dair hususlar1 da içerir. Şöyle ki; nice kimseler ilmi gerçekleri bozarlar, kötüye kullanırlar, onları kendi gönüllerine göre evirip çevirerek aslından çıkarırlar. Bu durumun İsrailoğulları'nda çok vaki olduğunu söyleyen Elmalılı,

35 Bilmen, Tefsîr, III, 1107.

36 Mâide 5/15.

37 Taberî, Câmiü'l-beyân, I, 569.

38 Muhammed Abdüh- Reşid Rızâ, Tefsìru'l-menâr, Dâru'l-ma'rife, Beyrut ts, , I, 292.

39 Hâzin, Lübâbü't-te'vîl, I, 40. 
İsrailoğulları'nın kendi yazdıkları fikirleri, tevilleri, tercümeleri Tevrât'ın aslı ile karıştırdıklarını ayrılamaz bir hale getirdiklerini ve Hz. Peygamber'e ait vasıflarda yaptıkları gibi geçmiş kitaplardaki âyetleri sakladıklarını belirtir. Bu konuda şu âyeti de delil getirir: "Yazıklar olsun o kimselere ki, kitabr elleriyle yažp, sonra 'bu Allab katindandir' derler."'(Bakara 2/79) Bu âyette ve bunun gibi diğger başka âyetlerde de belirtildiği üzere bunların Tevrât'ın aslını koruyamadıkları ve kendi yazdıkları tercümeleri Allah'ın kitabı diye Tevrât yerine koyduklarını da belirten Elmalılı, İsrailoğulları'nın ilmi meselelerde de gerçeği takip etmeyerek kendi gönüllerine ve arzularına göre açıklamada bulunduklarını, kendi hevalarına tabi olduklarını da bu âyet 1şığında açıklamışır. Ayrıca Elmalılı'ya göre, bu âyetteki yasaklama İsrailoğullarının bilginlerine yönelik yapılmıştır. ${ }^{40} \mathrm{Bu}$ âyetin Yahûdîler hakkında nazil olduğunu söyleyen Vehbi Efendi, Yüce Allah'ın onlara hitaben, size nazil olan hakkı kendi arzunuza göre elinizle yazdığınız batıla karıştırmayın ve hak olduğunu bildiğiniz halde gerçeği saklayıp, batılı yaymayın, uyarısında bulunduğunu açılamıştır. ${ }^{41}$ Vehbi Efendi'nin bu âyeti açılamasından, Yahûdîler'in kitaplarını lafzî olarak da tahrîf ettikleri anlaşılmaktadır. Çünkü hakkı kendi elleriyle yazdıkları batılla değiştirmelerinden söz edilmektedir ki bu da metinde yapılan bir değişikliğe işaret etmektedir. Ayrıca Vehbi Efendi'nin açıklamalarından Yahûdîlerin Tevrât'ta yer alan hükümleri kendi yazdıklarıyla değiştirmek suretiyle hakkı sakladıklanı anlaşılmaktadır. Ancak burada bu saklama işini kimlerin yaptığına dair bir bilgi bulunmamaktadir.

Bilmen, bu âyetin İsrailoğullarına hitaben Hz. Peygamber'in vasıfları hakkındaki Tevrât âyetlerini kendi uydurdukları şeyler ile tebdîl ve tağyîr etmemelerini emrettiğini söyler. İsrailoğullarr'nın hakkı bile bile gizlemeye cüret ettiklerini de belirtir. ${ }^{42}$

\section{Bakara 2/140:}

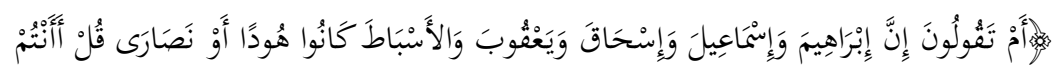$$
\text { CYoksa Sir }
$$
İbrâbim, İsmâil, İshak ve Yâkub'un ve onun evlatlarmm Yabûdî veya Horistiyan olduklarm me söylïyorsunuz? De ki: Siz mi daha iyi bileceksiniz. yoksa Allah mi? Allab'm, kitabı vasitasyyla kendisine ulastırdiğ hakikati saklayandan daba zalim kim olabilir? Allah yaptıklarmızdan babersiz değildir'.
}

\footnotetext{
40 Elmalıll, Hak Dini Kur'ân Dili, I, 284-286.

41 Vehbi Efendi, Hulâsatü'l-beyân, I, 113.

42 Bilmen, Tefsîr, I, 47.
} 
$\mathrm{Bu}$ âyet, Ehl-i kitabın geçmiş bütün peygamberlerin kendi milletlerinden olduğunu iddia etmeleri ve bu yüzden de Hz. Peygamber'in risaletini kabul etmemeleri ile ilgilidir. Yüce Allah, onların bu düşüncelerinde haksız olduklarını ve bu yüzden zalim olduklarını bildirmektedir. Çünkü Yahûdîlik ve Hiristiyanlik yukarıda sayılan peygamberlerden sonra şekillenmiştir. Dolayısıyla mesele onların iddia ettikleri gibi değildir. ${ }^{43}$ Yahûdîlik özel âyinleri ve düzenlemeleri ile M.Ö. dördüncü asırda şekillenmiştir. Hıristiyanlık ise Hz. Îsâ’nın dünyadan ayrılmasından sonra şekillenmiştir. Dolayısıyla bu tarihlerden önce yaşamış olan peygamberlerin, tarihî olarak bu dinlere mensup olmaları mümkün değildir.

Elmalılı, Hıristiyan ve Yahûdîlerin âyette adı geçen peygamberlerin kendilerinden olduklarını iddia etmeleri üzerine Yüce Allah bu âyette onları tekzib etmiştir. Âyette Yüce Allah, onların ne Hıristiyan ne de Yahûdî olduğunu sadece daha önce yaşamış birer geçmiş ümmet olduklarını belirtmiştir. Ayrıca İbrahim (a.s.)'ın hanif ve müslim olup müşriklerden olmadığını da açıklamıştır. Ehl-i kitaba hitaben bu gerçeği bile bile inkar ettiklerini söyleyen Yüce Allah, kendilerinin bildikleri, Allah tarafindan da sabit olmuş bir şahitliği gizledikleri için onları, en büyük haksızlığı ve zulmü yapmakla itham etmiştir. ${ }^{44}$ Ayrıca bu âyet tahrîf konusunda sadece Yahûdîlerin değil Hıristiyanların da bu işin içinde olduğunu haber vermektedir. Vehbi Efendi'ye göre; Yüce Allah'ın, Ehl-i kitab1 zalim olarak adlandırmasının sebebi, onlara kendi kitaplarında Hz. İbrahim'in ve diğer sayılan peygamberlerin hakiki misyonunun çarpitılması ve $\mathrm{Hz}$. Peygamber'in risaletinin inkar edilmesidir. ${ }^{45} \mathrm{Bu}$ âyetten yola çıkarak söyleyebiliriz ki Yahûdîler ve Hıristiyanlar kitaplarında yer alan hükümleri saklayıp, kendi fikirlerini ileri sürmek suretiyle kitaplarını tahrîf etmişlerdir. Ancak Vehbi Efendi Ehl-i kitabın âyetleri ne şekilde sakladıkları hususunda bir açıklama yapmamıştır. Dolayısıyla açıklamalarında onların tahrîfi lafzen mi manen mi yaptıkları hususuna dair de kesin bir bilgi bulunmamaktadır.

Bakara 2/146:

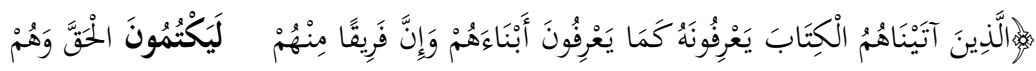

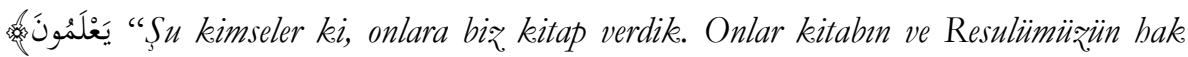
Resul olduğunu kendi oğullarm bildikleri gibi bilirler. Ve Ebl-i kitaptan bir firka elbette bakker saklarlar. Halbuki onlar Rabbin tarafindan gelen Kur an'm ve kiblenin bake olduğunu bilirler"
}

43 Bkz. Taberî, Câmiü'l-beyân, III, 124.

44 Elmalıli, Hak Dini Kur'ân Dili, I, 427-428.

45 Vehbi Efendi, Hulâsatü'l-beyân, I, 240, 241. 
Râzî (ö. 606/1210) ve Hâzin'e göre âyette Ehl-i kitaptan kastedilen Yahûdîler'in ve Hıristiyanlar'in ulemasıdır. ${ }^{46}$ Çünkü o günün şartlarında kutsal kitapları sadece din adamlarından belli bir zümre biliyordu. Hatta Hıristiyanlıkta Protestan hareketleri bile buna karşı yapılmıştır. Taberî̀ye (ö. 310/923) göre Ehl-i kitap'ın burada bildiği şey kıblenin kabe olduğudur. ${ }^{47}$ Râzîye göre bu görüş zayıftır. Hakikatte bilinen ve gizlenen şey Hz. Peygamberin nübüvvetidir. Çünkü bu ifadelerden önce Hz. Peygambere bilgilerin geldiğinden bahsedilmektedir ki bunlar da nübüvvettir. Kur'ân Hz. Peygamberin nübüvvetinin diğer kitaplarda bulunduğunu haber vermekte lakin kıble ile ilgili bir haber vermemektedir. ${ }^{48}$ Elmalılı'ya göre, bu âyet, Ehl-i kitabın alimlerini kapsamaktadır. Onlar kendi kitaplarında son peygambere dair haberleri okumuşlar ve $\mathrm{Hz}$. Peygamber'in o peygamber olduğunu şüphe olmayacak şekilde anlamışlardı. Bunu, çocuklarını bildikleri gibi kesin bir şekilde biliyorlardı. Bu kadar kesin olarak bildikleri halde, Ehl-i kitabın alimleri, O peygambere iman etmemişler, bile bile gerçeği gizledikleri için halktan daha fazla yerilen ve ayıplanan inatçı kafirlerden olmuşlardır. Elmalılı'ya göre bu âyet ayrıca, iman için sadece ilim ve bilginin yeterli olmadığına da delildir. ${ }^{49}$

Vehbi Efendi, Râzî ve Hâzin'e dayandırdığı görüşe göre, bu âyette Ehl-i kitaptan kastedilenin Yahûdî ve Hiristiyan uleması olduğudur. Çünkü âyette hakk1 saklayanların Ehl-i kitaptan bir firka olduğu belirtilir. Bu ulema, kitaplarında geçen $\mathrm{Hz}$. Peygamber ile ilgili hüküm ve vasıfları kendi oğullarını bildikleri gibi bilirler ancak kabul etmezler. Bu görüşünü Vehbi Efendi, bir hadîsle destekler. Abdullah b. Selam, Hz. Ömer'in bir sorusu üzerine bu âyetin manâsına verdiği cevap şöyledir: "Resûlullah'ı görünce Tevrât'ta beyan olunan vasiflara uygun hak resûl olduğunu oğlum gibi bildim. Belki oğlumdan şüphem olabilir ama ondan asla şüphem olmadı." İsste Abdullah b. Selam'ın da belirttiği üzere Resûlullah'ın vasıfları ve gerçek peygamber olduğu kitaplarında belirtildiği halde Ehl-i kitabın ulemalarının kibirleri ve inatları bunu kabullenmelerine mani olmuş, gerçekleri avamdan saklamışlardır. ${ }^{50}$

Bilmen'e göre bu âyet, Hz. Peygamber'in bütün vasıflarının geçmiş kitaplarda zikredildiğini gösterir. Yahûdî ve Hıristiyanların alimleri, kendi oğullarını tanıyıp bildikleri gibi Hz. Muhammed'i de tanıyıp bilirlerdi. Fakat onlardan bir firka, bildikleri halde gerçeği gizlerler ve Hz. Peygamber'in nübüvvetini tasdik etmezlerdi. ${ }^{51}$ Bilmen'in açıklamalarından anladığımıza göre

46 Râzî, Mefâtîhu'l-ğayb, IV, 110; Hâzin, Lübâbü't-te'vîl, I, 90.

47 Taberî, Câmiü'l-beyân, III, 187.

48 Râzî, Mefâtîhu'l-ğayb, IV, 112.

49 Elmalılı, Hak Dini Kur'ân Dili, I, 438, 439.

50 Vehbi Efendi, Hulâsatü'l-beyân, I, 255.

51 Bilmen, Tefsîr, I, 141. 
'onlardan bir fırka'yla kastedilen bir grup alimlerdir. Yani bu açıklamaya göre tahrîfi yapanlar Ehl-i kitabın alimlerinin hepsi değil onlardan bir gruptur. Yani her dinin ve kitabın Hz. Peygamber'den bahsetmekte olduğunu söyleyen Bilmen, böyle bir yorumu ilgili âyetten çıkarmaktadır ki bu Bilmen'e ait orijinal bir yorumdur.

\section{Bakara 2/159:}

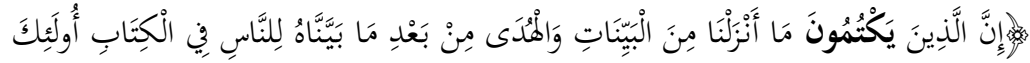

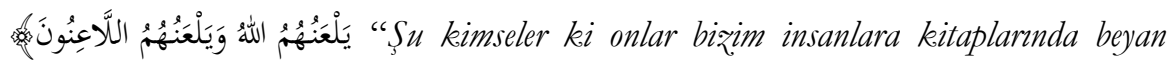

Yüce Allah bu âyette, kendilerine nazil olan kitaplarda geçen ilahi hükümleri saklayan kimselere lanet edildiğinden bahseder. Lanet, Yüce Allah'ın rahmetinden uzaklaşmak anlamlarına gelir. Âyetteki lanet ahirette cehenneme gitmek ve cennetten mahrum kalmak anlamındadır. ${ }^{52}$ Müfessirlerin çoğuna göre Tevrât'ın hükümlerini saklayan ve ona yanliş yorumlar veren Yahûdîlerdir. ${ }^{53}$ Râzî anlamın tahsîs edilemeyip genel olduğuna vurgu yapar. ${ }^{54}$ Ancak Abdüh'ün (ö. 1906)de dediği gibi 40. âyetten itibaren Yahûdîlerden bahsedilir. ${ }^{55}$ Elmalilı da, bu âyetin sebeb-i nüzûlünün, Ensar'dan bir topluluğun, Yahûdîlere Hz. Peygamber'in Tevrât'taki vasıflarını ve ahkamla ilgili bazı âyetleri sormaları ve Yahûdîlerin gizleyip gerçeği söylememeleri olduğunu belirtir. Ayrıca İbn Abbas, Mücahid, Hasan, Katade, Rebi‘, Süddi ve Asım’a dayandırdığı rivayete göre bu âyetin Yahûdî ve Hıristiyan Ehl-i kitabın alimleri hakkında indiğini söylemiştir. Elmalıı bu âyetin tefsirinde şu açıklamayı da yapar: Her ne kadar âyetin nüzûl sebebi özel olsa da hükmün genel olmasına mani değildir. Yani âyetin hükmü, din işleriyle ilgili bildiği herhangi bir gerçeği gizleyip söylemeyenlerin hepsini içine almaktadır. ${ }^{56}$ Yani Elmalılı'nın bu yorumuna göre, Müslümanlar da Kur'ân'da yer alan bir gerçeği, bildiklerini açıklamayıp gizlerlerse onlar da Allah'ın yerdiği büyük bir zulüm olarak nitelendirdiği Ehl-i kitabın kitaplarını tahrîf etmeleri gibi küfrane bir sıfatı taklit etmiş olurlar ki bu fiil tahrîf sorumluluğunu Müslümanlara da yükler. Vehbi Efendi, bu âyetin dini hükümleri saklayan herkes için geçerli olduğunu söyler. ${ }^{57} \mathrm{Bu}$ kişilerin Yahûdîler olduğu

\footnotetext{
52 İbn Aşûr, et-Tahrîr ve't-tenvîr, II, 68.

53 Râzî, Mefâtîhu'l-ğayb, IV , 139, 140.

54 Râzî, Mefâtîhu'l-ğayb, IV , 139, 140.

55 Muhammed Abdüh, Tefsîrul-menâr, I, 48.

56 Elmalıli, Hak Dini Kur'ân Dili, I, 461.

57 Vehbi Efendi, Hulâsatü'l-beyân, I, 271.
} 
görüşünü ileri sürenler olduğunu belirten Vehbi Efendi, Hıristiyanlar olarak yorumlayan kişiler olduğundan bahsetmez. Ama dini hükümleri saklayan herkes için âyetin geçerli olduğunu söylemesi dolaylı olarak Hıristiyanları da âyetin kapsamına almaktadır kanaatindeyiz. Çünkü onda daha çok Râzî etkisi görülmektedir. Bundan dolayı da o, Râzî gibi âyeti âmm olarak yorumlar ${ }^{58}$. Bilmen'e göre âyet, Hz. Peygamber'in vasıflarını, İslamiyet'in hak din olduğunu kitaplarında görüp okumuş bir takım Yahûdî alimleri hakkında nazil olmuştur. Ensardan bazıları, Resûlullah'ın Tevrât'ta yazılı olan vasıflarını Yahûdî alimlerden sormuşlar onlar ise bunu bildikleri halde saklayıp açıklamamışlardır. Yüce Allah, Resûlullah'ın vasıfları, O'na tabi olmanın vücubiyetine delalet eden mucizeleri Tevrât'ta ve diğer semavi kitaplarda açıkça belirttiği halde Yahûdî bilginleri bir kıskançlık ve küfr-i inadi eseri olarak bunları halka bildirmemişler, bu yüzden de Allah'n rahmetinden ebediyyen mahrum kalmışlardır. ${ }^{59}$

Bakara 2/174:

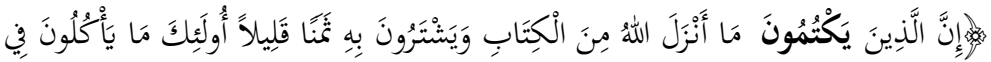

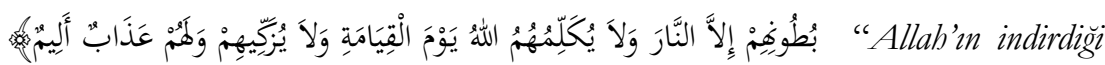

Râzî, bu âyetin Yahûdî uleması hakkında nazil olduğunu söyler. Onlar Hz. Muhammed'le ilgili bazı gerçekleri kendi halklarından saklamışlar, bazı yerleri de menfaatleri için keyfí olarak tevil etmişlerdir. ${ }^{60}$ Elmalıll, bu âyeti şöyle açılamıştır: Allah'ın indirdiği kitabı Yahûdî alimlerin yaptığı gibi az bir değer karşıllı̆ında gizleyenlerin aldıkları bedellerin karşıllı̆ı gerçek bir ateş olacak ve onlar ebedi olarak yanacaklardır. Aldıkları karşılık ne kadar çok gibi görünse de gerçekte az bir dünya menfaatidir. ${ }^{61}$ Vehbi Efendi'ye göre, ahkam1 saklamak; kitabın lafızlanını değiştirmekle mümkün olabilse de te'vîl şeklinde manen yapmak daha kolaydır. Çünkü -belli ölçüde tahrîf olsa da- mütevatir olan kitaplarda yer alan lafizları değiştirmek zor olup âyeti arzuya göre tevil etmek suretiyle âyeti hakiki manâsından çıkarmak daha kolaydır. ${ }^{62}$

58 Bkz. Râzî, Mefâtîhu'l-ğayb, IV, 139, 140.

59 Bilmen, Tefsîr, I, 152.

60 Râzî, Mefâtîhu'l-ğayb, V, 204.

61 Elmalılı, Hak Dini Kur'ân Dili, I, 487, 488.

62 Vehbi Efendi, Hulâsatü'l-beyân, I, 291. 


\title{
Âli İmran 3/71:
}

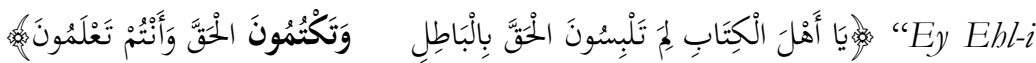 \\ kitap! Hakker batıla ne için karsştrnr ve bakker bake olduğunu bildiğiniz halde niçin \\ saklarsiniz?".
}

Taberî tefsîrinde bu âyetle ilgili olarak "illahi kelamla kendi uydurduklarını karıştırıyorlar, müminlere karşı ikili davranıyorlar, Tevrât'ta Hz. Peygamberle ilgili şeyleri değiştiriyorlar, İslâmın Hz. Mûsâ'yı kabul etmesini kendilerinin haklı olduklarına delil gösteriyorlar" şeklinde yorum yapmıştır. ${ }^{63}$ İbn Atıyye (ö. 546/1151) de Taberî̀ye yakın açıklamalar yapmaktadır. ${ }^{64}$ Râzî bir önceki âyetin tefsîrinde tahrîfin iki şekli üzerine vurgu yapar. ${ }^{65}$ Râzî̀ye göre bu âyet, Ehl-i kitabın iki konudaki büyük tahrîfiyle alakalıdır. İlk olarak $\mathrm{Hz}$. Peygamberin nübüvvetini kasden inkar etmeleri; ikinci olarak da onunla ilgili pasajları farklı yorumlamalarıdır. ${ }^{66}$ Elmalılı hakkı batıla karıştıranların Ehl-i kitabın bir kısmı olduğunu vurgular ve buna örnek getirir. Hayber ve Ureyne Yahûdîleri hahamlarından on iki kişi anlaşmışlar, birbirlerine: Haydi bir gün sadece söz ile Muhammed'in dinine giriniz, akşam üzeri de; kitaplarımıza baktık, alimlerimize danıştık ve Muhammed'in Tevrât'ta anlatılan o peygamber olmadığını anladık, bu yalan ve batıl bir dinmiş, deyiniz ve inkar edip çıkınız. Böyle yaparsanız Ashab da şek ve şüpheye düşerler, demişlerdi. ${ }^{67} \mathrm{Bu}$ örnekte de görüldüğü gibi Ehl-i kitabın alimlerinden bir kısmı bile bile gerçeği inkar etmekte ve halka yalanlar söylemektedir. Vehbi Efendi, bu âyetin tefsîrinde de Fahreddin Râzî̀nin görüşüne yer vermekte ve Ehl-i kitabın iki sıfatının olduğunu belirtmektedir. $\mathrm{Bu}$ sifatlardan ilki, Hz. Muhammed (s.a.s)'in peygamberliğini kalpleriyle bildikleri halde lisanlarıla inkar etmeleri; İkincisi ise, Resûlullah'ı ahvali kitaplarında açılanan vasıflara uygunluk gösterdiği halde onların o âyetleri tahrîfle hakkı batıla karıştırmaları ve insanlar arasına şüphe verecek sözler atmakla hakkı örtüp batılı yaymalarıdır. Çünkü onlar, Yüce Allah tarafindan nazil olunan âyetleri kendilerinin tağyîr ettiklerine ve Resûlullah'nn vasıflarına delalet edenleri delalet etmeyenlere karıştırırlar ve arzularına göre tevilde bulunup halk1 aldatırlard1. ${ }^{68}$ Hulasa Vehbi Efendi daha çok delailü'nnübüvvetle ilgili bilgilerin tahrîfini kabul etmekte ama bu âyet bağlamında Tevrât'ın metin olarak güvenilirliğini açıçca inkar etmemektedir. Bilmen, bu

63 Taberî, Câmiü'l-beyân, VI, 504.

64 İbn Atiyye, et-Tabrir ve't-tenvir, I, 452, 453.

65 Râzî, Mefâtîhu'l-ğayb, VIII, 255.

66 Râzî, Mefâtî̉bu'l-ğayb, VIII, 256.

67 Elmalılı, Hak Dini Kur'ân Dili, II, 390.

68 Vehbi Efendi, Hulâsatü'l-beyân, II, 634. 
âyette Ehl-i kitaba hitaben Kur'an'da ve kendi kitaplarında sabit olan Resûlullah'ın vasıflarını onların örtbas ettiklerini söylemiştir. ${ }^{69}$

\section{Âli İmran 3/187:}

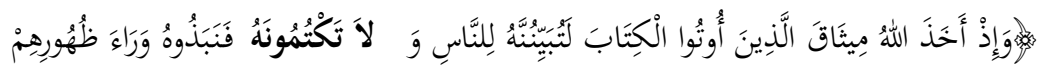

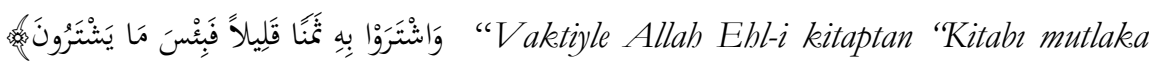

Elmalıl, "Allah kendilerine kitap verilmiş okur-yazar olanlardan, o kitabı veya o kitapta peygamberliğinin doğruluğu sabit olan son peygamberi insanlara hakkıyla açılayacaksınız ve onu gizlemeyeceksiniz diye söz almıştı. Kitap verilmiş olanlardan maksat, Ehl-i kitap olan Yahûdî ve Hiristiyan bilginlerdir. İşte bunlar böyle anlaşma yaptıkları halde anlaşmaları yerine getirmediler, gerçeği gizlediler, Peygambere ve Müslümanlara eziyet verip rahatsız etmeye kalkıştılar. Bunu önce Yahûdîler yapmış, sonra Hıristiyanlar da o yola girmiştir. Bunlar dünya hayatına aldanarak az bir para veya menfaat karşıllı̆ında susarak veya tevil ederek veya bozarak veya görmezlikten gelerek hakk1 gizlediler. Bu bedel ne kadar çok olursa olsun ebedi olan ahiret sevabına göre pek az bir bedeldir" açılamasını yapar. Elmalılı, bu durumda olan Müslümanların da olduğuna dikkat çekmiştir. Bu şekilde kendi arzularına göre cevap bulmak isteyen cahiller alimleri âyetleri değiştirmeye teşvik etmişlerdir. ${ }^{70}$

Vehbi Efendi, bu âyette Ehl-i kitaptan kastedilenin Yahûdîler ve Hıristiyanların olduğunu söylemiştir. Kitapları Tevrât ve İncîl'de, Ehl-i kitaba, ahir zaman nebisinin vasıflarını açıklamaları ve saklamamaları emredildiği halde Resûlullah'ın zuhurundan sonra hasetlerinden dolayı kitaplarının hilafina hareket etmeleri ve bir takım müfsitlerin arzularına göre tevil yapmak suretiyle karşıllı̆ında para almaları, Vehbi Efendi’nin bu âyetten çıkardığ1 yorumlardır. ${ }^{71}$ Vehbi Efendi, şimdiye kadar gördüğ̈̈müz diğer âyetlerde Hıristiyanların tahrîf yaptığı ile ilgili olarak bir açıklamada bulunmamıștı. $\mathrm{O}$, bu âyette Yahûdîlerle birlikte Hıristiyanları da zikretmiştir. Burada da lafzen bir tahrîften söz edilmemekte tevil yoluyla yapılan ve kitaplarındaki ahkamı halktan saklamak suretiyle yapilan bir tahrîften bahsedilmemektedir. Bir sonraki âyette bu âyette bahsedilen Ehl-i kitap için acı bir azap olduğu da bildirilir. Bu âyetin yorumunda ise Vehbi Efendi, sadece Yahûdîler'e âyeti has kılmakta ve onların Tevrât'in

69 Bilmen, Tefsîr, I, 394.

70 Elmalıl, Hak Dini Kur'ân Dili, II, 481-482.

71 Vehbi Efendi, Hulâsatü'l-beyân, II, 805, 806.. 
bazen lafzını bazen de ahkamını tağyîr ettiklerini belirtir. Genellikle Yahûdîlerin kitaplarını tahrîf ettikleri ile ilgili yorumlarla karşılaşmamızın sebebini İncîl'in yazılı bir metin olarak indirilmemesine bağlayabiliriz.

Bilmen, "Yüce Allah, bu âyette Resûlüne, bir zamanlar kendilerine Tevrât ve İncîl verilmiş olan Yahûdî ve Hıristiyan alimlerinden o kitabı insanlara tağyîr ve tebdîl etmeksizin telkin etmeleri, onun hükümlerini olduğu gibi tebliğ etmeleri üzerine bir söz ve teminat aldığını bildirmiştir. Kendilerine böyle kitap verilmiş olanlar ise Allah'a verdikleri sözü, üstlendikleri vazifeyi omuzlarının arkasına atıp sözlerine riayet etmemişler, onun tersine hareket etmişlerdir. Karşılı̆̆ında kıymetsiz bir şey satın alıp dünya varlığı için ebedi hayatlarını tehlikeye düşürmüşlerdir" der. ${ }^{72}$

Kitmân kelimesini müfessirler, her ne kadar Yahûdîlerin $\mathrm{Hz}$. peygamberin peygamberliğini gizlemeleri konusunda açılasalar da âyetin bütününe, siyak ve sibakına bakarak kutsal kitapların lafzen ve manen tahriffine delil göstermişlerdir. Peygamberliği gizleme bağlamında ilk defa Hiristiyanlar da Bakara 2/140 âyetinde muharrifler gurubuna dahil edilmiştir. Kitmân kelimesinin anlamından yola çıkarak kutsal kitapları tahrîfin bir yönünün de gizleme şeklinde olduğudur. Bu da daha çok $\mathrm{Hz}$. peygamber döneminde gerçekleşmiştir. Burada metinden çok anlam tahrîfi anlaşılmalıdır. Çünkü mevcut olan bir şey gizlenmektedir.

\section{Lebs Kelimesi Etrafinda Yapilan Yorumlar}

Lebs, hak ile batılın karıștırılması anlamında Kurân'da iki âyette kullanilmaktadır. Bunlar da Bakara 2/42 ve Âli İmran 3/71 âyetleridir. Mezkûr kelimelerin kitmân kelimesinden önce kullanılması tahrîfteki sıralamayı ifade etmektedir. Demek ki Ehl-i kitap değişik şekillerde gizleme yapmıstır. Bunların da bazıları ilahi hükümlerle beşeri hükümlerin birbirine karıştırlması şeklindedir.

Bakara 42:

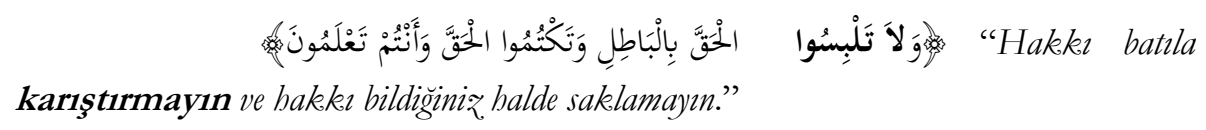

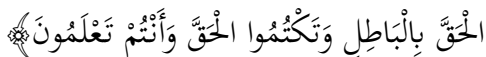$$
\text { “Haker batula }
$$

karıştırmayın ve hakke bildiğiniz, halde saklamayn."

Âyette Kur'ân'ın gerçek kitap, Hz. Peygamberin de hak peygamber olduğu bildirilmektedir. İnkarcıların hak ile batılı birbirine karıştırarak gerçeği gizlememeleri istenmiştir. Âyette Yahûdîlerin kitaplarına ilave yaparak gerçeği gizlediklerine; ${ }^{73} \mathrm{~Hz}$. Peygamberin geleceğinin Tevrât'ta haber verildiği gerçeğini

72 Bilmen, Tefsîr, I, 519.

73 Taberî, Câmiü'l-beyân, I, 255. 
saklamalarına işaret edilir, ${ }^{74}$ Hâzin'e göre âyette geçen hak Resûlullah'ın vasıfları, batıl da bizzat sonradan yapılan ilaveler yani beşerî müdahalelerdir. ${ }^{75}$ Bu âyet Elmalılı'ya göre çok kapsamlı olup, ilme ve amele dair hususları da içine alır. Şöyle ki; nice kimseler ilmi gerçekleri bozarlar, kötüye kullanırlar, onları kendi gönüllerine göre evirip çevirerek aslından çıkarırlar. Bu durumun İsrailoğulları'nda çok sık gerçekleştiğini söyleyen Elmalılı, İsrailoğulları'nın kendi yazdıkları fikirleri, tevilleri, tercümeleri Tevrât'ın ası ile karıştırdıklarını, ayrlamaz bir hale getirdiklerini ve Hz. Peygamber'e ait vasıflarda yaptıkları gibi geçmiş kitaplardaki âyetleri de sakladıklarını belirtir. ${ }^{76}$

Bu âyetin Yahûdîler hakkında nazil olduğunu söyleyen Vehbi Efendi, Yüce Allah'ın onlara hitaben, "size nazil olan hakk1 kendi arzunuza göre elinizle yazdığınız batıla karıştırmayın ve hak olduğunu bildiğiniz halde onu saklayıp batılı yaymayın", uyarısında bulunduğunu açıklamıştır. Zira batılı yaymak için hakkı saklamakta büyük bir zarar ve fitne vardır. Hakkı bilenlere onu açıklamak vacip olduğundan hakkı saklamak haramdır. ${ }^{77}$ Tahrîf konusunda bu âyette de Hiristiyanlarla ilgili bir yorumda bulunmayan Vehbi Efendi'nin âyeti tefsîrinden Yahûdîler'in kitaplarını lafzî olarak da tahrîf ettikleri anlaşılmaktadır. Çünkü hakk1 kendi elleriyle yazdıkları batılla değiştirmelerinden söz edilmektedir ki bu da metinde yapılan bir değişikliğe işaret etmektedir. Ayrıca Vehbi Efendi’nin açılamalarından Yahûdîlerin Tevrât'ta yer alan hükümleri kendi yazdıklarıyla değiştirmek suretiyle hakkı sakladıkları da anlaşılmaktadır. Ancak burada bu saklama işini kimlerin yaptığına dair bir bilgi bulunmamaktadır. Bilmen, bu âyetin İsrailoğullarına hitaben Hz. Peygamber'in vasıfları hakkındaki Tevrât âyetlerini kendi uydurdukları şeyler ile tebdîl ve tağyîr etmemelerini emrettiğini söyler. İsrailoğulları'nın hakk1 bile bile gizlemeye cüret ettiklerini de belirtir. ${ }^{78}$ Bir önceki âyetle münasebetine bakıldığında âyetin İsrailoğulları'na hitap ettiğini anliyoruz.

\section{Âli İmran 3/71:}

$$
\text { “Ey Ebl-i }
$$

kitap! Hake. batıla ne için karıştırır ve baker hake olduğunu bildiğiniz balde niçin saklarsma?"

\footnotetext{
74 Muhammed Abdüh, Tefsîru'l-menâr, I, 292.

75 Hâzin, Lübâbü't-te'vîl, I, 40, 41.

76 Elmalılı, Hak Dini Kur'ân Dili, I, 284-286.

77 Vehbi Efendi, Hulâsatü'l-beyân, I, 113.

78 Bilmen, Tefsîr, I, 47.
} 
Taberî̀ye göre, hem Yahûdîler hem de Hiristiyanlar kalben olmadığ1 halde dilleriyle Hz. Peygamberi ve O'na indirilen şeyleri inkar etmişlerdir. ${ }^{79}$ Râzî’ye göre bu âyette belirtildiği üzere Ehl-i kitabın başlıca iki kötü sıfatı vardır. $\mathrm{Bu}$ sifatlardan ilki, Hz. Muhammed (s.a.s)'in peygamberliğini kalpleriyle bildikleri halde lisanlarıla inkar etmeleri; İkincisi ise, Resûlullah'n ahvali kitaplarında açıklanan vasıflara uygunluk gösterdiği halde onların o âyetleri tahrîfle hakkı batıla karıştırmaları ve insanlar arasına şüphe verecek sözler atmakla hakk1 örtüp batılı yaymalarıdır. ${ }^{80}$ Elmalılı hakk1 batıla karıștıranların Ehl-i kitabın bir kısmı olduğunu vurgular ve buna Hayber ve Ureyne Yahûdîlerini örnek verir. ${ }^{81}$ Onlar Ehl-i kitabın alimlerinden olmasına rağmen bile bile gerçeği inkar etmiş ve halka yalan söylemiştir. Vehbi Efendi, bu âyetin tefsîrinde de Râzî̀yle mutabık olup ilaveten şöyle demektedir: "Onlar, Yüce Allah tarafindan nazil olunan âyetleri kendilerinin tağyîr ettiklerine ve Resûlullah'ın vasıflarına delalet edenleri delalet etmeyenlere karıştırırlar ve arzularına göre tevilde bulunup halkı aldatırlardı". ${ }^{22}$ Hulasa Vehbi Efendi, daha çok delâilü'n-nübüvvetle ilgili bilgilerin tahrîfini kabul etmekte ve Tevrât'in metin olarak güvenilirliğini inkar etmemektedir. Ancak bu güvenirlilik sadece ilgili konu hakkındadır. Bilmen bu âyette Ehl-i kitaba hitaben Kur'an'da ve kendi kitaplarında sabit olan Resûlullah'n vasıflarını örtbas ettiklerini söylemiştir. $\mathrm{Bu}$ şekilde tahrîfe saptıkları belirtilmiş ve $\mathrm{Hz}$. Peygamberin vasıflarının ve peygamberliğinin onların kitaplarında yazılmış olması hasebiyle bu işi bilerek yaptıkları vurgulanmıştır. ${ }^{83}$

Lebs kelimesinin tefsîrlerine bakıldığında, onun da kitmân kelimesi gibi daha çok yorum tahrîfine işaret etmektedir. Kitmân kelimesiyle aynı âyetlerde kullanılması da ayrıca manidardır. Yedi âyette geçen kitmân bir şeyi gizlemektir, lakin iki yerde "lebs"le kullanılması bu gizleme işinin bazen de karıştırarak yapıldığını gösterir. Bizce yapılan bu karıştırma işi daha çok yorumda olsa da metinde de bazı karışıklıklar yapmaları imkan dahilindedir.

\section{Leyy Kelimesi Etrafinda Yapılan Yorumlar}

Leyy, Medine Yahûdîlerinin bir kelimenin telafffuzunu hafif değiștirerek kendi dillerindeki bir kelimeye yaklaștırmalarıdır. Böylece Arapça bir lafza İbranice anlam vermek istemişlerdir. Daha önce de onlar kendi dillerinde "hıtta" ya yakın telaffuzlu bir kavram olan "hınta" demişlerdi.

\footnotetext{
Taberî, Câmiü'l-beyân, VI, 503, 504.

Râzî, Mefâtîhu'l-ğayb, VIII, 256.

Elmalılı, Hak Dini Kur'ân Dili, II, 390.

Vehbi Efendi, Hulâsatül-beyân, II, 634.

83 Bilmen, Tefsîr, I, 394.
} 


\section{Âli İmran 3/78:}

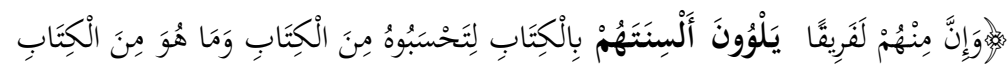

$$
\begin{aligned}
& \text { "Yabûdîlerden }
\end{aligned}
$$

bir firka kitapta dillerini eğip bükerler ve tahrifle icad ettikleri lafizlar Tevrât'in ibaresine karsstorrilar ki siz o tahrîf olunan lafizlar kitaptan zannedersiniz, balbuki o lafizlar kitaptan değildir. Ve tabrîf ettikleri lafızlarn taraf-ı ilabiden olduğunu söylerler. Halbuki taraf- ilahiden değildir. Zira; kendileri icat etmistitir ve Yüce Allab'a iftira eder, yalan söylerler, halbuki yalan olduğunu bilirler."

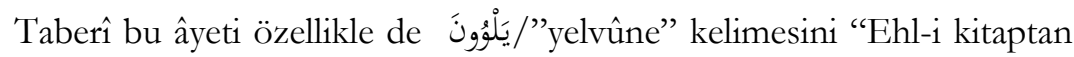
belli bir zümre kendilerine indirilen kitabı dillerini eğip bükerek tahrîf ederler" şeklinde açıklar. Bu da ona yalan ve batıl şeyleri dahil etmekle olmaktadır. ${ }^{84}$ Zemahşerî leyy ifadesini "doğru şeklinin yerine başka şeklinin okunması ya da onda olmayan ifadelerin benzetilerek okunması" olduğunu ifade eder. ${ }^{85}$ Kaffâl'a göre bu İbranicenin de Arapça gibi harekeleri değiştirilerek farklı anlamlarda okunmasıdır. ${ }^{86}$ Müfessirlerin çoğunluğuna göre ise bu Hz. Peygamber'in nübüvvetini ve sıfatlarını anlașılmaz hale getirmektir ${ }^{87}$. Kısaca leyy a) Kitaptaki ifadeleri değiştirme; b) kendi arzularına göre yorumlama anlamlarına gelir. Abdüh'a göre âyet ilk etapta Medine'de yaşayan Ehl-i kitabı konu alsa da onlar gibi olan herkesi kapsar. Medine Yahûdîlerinden bir gurup Hz. peygamberin sıfatlarını ve bazı ahkamı değiştirerek yeni bir kitap yazarlar ve böylece Tevrât tahrîf edilmiş olur. Aynı şekilde günümüz Müslümanları da lafzen olmasa bile manen benzer tahrîfler yapmaktadır ${ }^{88}$. Elmalılı bu âyetle ilgili pek bir açıklamada bulunmamış; kitap ehli içinde kitap adına ağızlarını eğen, bile bile yalan söyleyerek insanları Hak'tan ayırıp batıla saptırmak isteyen bir grubun bulunduğunu; halbuki Allah'ın kitap ve peygamberlik verdiği bütün nebilerin ve resûllerin bunların isnat ettikleri yalandan uzak olduklarını söylemekle yetinmiştir. Ve sonraki âyette (Âli İmran 81) belirtildiği üzere Yüce Allah, bütün peygamberlerden, yanlarında bulunan kitapları doğrulayıcı bir peygamber geldiğinde O'na muhakkak inanmaları ve yardım etmeleri üzerine ahd almıștı. Hepsi, kendilerini tasdik eden Hz. Muhammed'e iman etmek ve O'na yardım etmek için Allah'a söz vermişlerdi. ${ }^{89}$ Dolayısıyla Ehl-i kitabın yaptıkları tahrîfin

84 Taberî, Câmiü'l-beyân, VI, 535, 536.

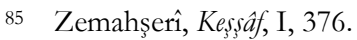

86 Aktaran Râzî, Mefâtîhu'l-ğayb, VIII, 267, 268.

87 Râzî, Mefâtîhu'l-ğayb, VIII, 267, 268.

88 Abdüh, Tefsîru'l-menâr, III, 343, 345.

89 Elmalılı, Hak Dini Kur'ân Dili, II, 393, 394. 
aynı zamanda kendi peygamberlerinin de yolundan gitmediklerinin bir göstergesidir.

Vehbi Efendi, Yahûdîlerden bir gurup, Resûlullah'a ve O'nun getirdiği dine düşmanlıklarından dolayı Tevrât'ta yer alan onun isim ve sıfatını değiștirerek insanlara bu şekilde yaymışlardır. İnsanları dalalete düşürmek için lisanlarını kitabın lafızlarıyla dürerler, bükerler ve Tevrât'ın lafızlarından tahrîf ettikleri lafızlara meylederler ki o lafizlar Tevrât'tan zannedilsin, halbuki Tevrât'tan değildir. Hatta o kelime itibariyle kitaptan olmadığı gibi işaret, delalet ve tevil itibariyle de kitaba uygun değildir. Yani Vehbi Efendi'nin bu açılamasından biz Yahûdîlerin, kitaplarını hem lafzen hem manen tahrîf ettikleri sonucuna varıyoruz. Onlar kitaplarında tahrîf yaparak kendi uydurdukları şeylerin Allah'tan geldiğini iddia ederler. Bu lafızların kendi uydurmaları olduğunu bildikleri halde Allah'tan geldiğini iddia ederek yalan söylerler. Âyette geçen يَلْوُونَ/"yelvûne" kelimesinin anlamı; dillerini haktan batıla ve Allah'ın kelamından kendi uydurdukları lafizlara döndürmeleridir, Yani: eğmek, bükmektir. Hileyle kitaptan olmayan şeyi insanlara kitaptan gibi göstermekle dalalete düşmektir. Tevrât'in âyetleri Yahûdîlere göre mütevatirse de, Tevrât'ın hıfzı mümkün olmadığından ve zamanın geçmesi sonucu bazı yerlerde Tevrât's tilavet eden kıraat ehli az olduğundan Tevrât âyetleri mütevatir değildir. Bu sebepten ulemanın bir kısmı tarafından, yöneticilerin arzusu ve ileri gelenlerin hatırı için bazı âyetleri kaldırıp yerine kendi elleriyle yazdıklanı yalanları Tevrât âyeti diyerek halka tebliğ etmek suretiyle tahrîf vuku bulduğu gibi, bazı âyetlerin manâlarını anlamak gerektiğinden yine bir kısım ulemanın âyetlerin manâlarını değiştirmeleri suretiyle de tahrîf vuku bulmuştur. ${ }^{90}$ Vehbi Efendi'nin bu yorumundan anladığımıza göre Tevrât'ın tahrîf edilmeye müsait olmasındaki en önemli sebep, Tevrât'nn mütevatir olmaması, kitabın sadece kıraat ehli olan alimlerin elinde olmasıdır. Bu yüzden Tevrât'ın tahrifinden bahsedilirken tahrîfi, bir kısım alimlerin yaptıkları vurgulanmaktadır. Vehbi Efendi, bu açıklamalarından sonra, Tevrât ve İncîl'in lafızlarında tahrîfin mümkün olduğu ve vuku bulduğundan, manâlarını ve lafzını her zamanda arzuya göre değiştirdiklerinden yola çıarak gerek Tevrât'ın ve gerekse İncîl'in ahkamına itimat kalmadığını belirtmiştir. Dolayısıyla Tevrât'ın Hz. Mûsâ'dan ve İncîl'in Hz. Îsâ'dan işitildiği gibi tek birer nüshalarını bile bulmak mümkün değildir. Hatta bir beldede bulunan kitab-1 mukaddesin âyetleri ile diğer beldede bulunan kitab-1 mukaddesin âyetleri birbirine muhaliftir. ${ }^{91}$

Bilmen'e göre Ehl-i kitaptan bir grubun, kitaplarını münkirane bir şekilde tahrîfe cüret ettiklerini bildirmektedir. Ehl-i kitaptan Yahûdî

90 Vehbi Efendi, Hulâsatü'l-beyân, II, 646, 647.

91 Vehbi Efendi, Hulâsatü'l-beyân, II, 648. 
bilginlerinden bir grup ( Kab b. Eşref, Malik b. Sayf ve Hüvey b. Ahtap...) vardır ki bu grup Tevrât'ın âyetlerini okurken dillerini eğip bükerler, yani onları tağyîr ederler. Hz. Peygamber'in vasiflarına, recme dair âyetleri ve diğer âyetleri tebdîl ve tahrîfte bulunurlar. Tağyîr ve tahrîf ettikleri şey, Allah'ın kitabında olmamasına ve onların da bunu bilmelerine rağmen Allah'n kitabında olduğunu iddia ederek kendileri kitaptan sanılsın yaptıklarıdır. Sırf dünyalık menfaatler, yalnız kendi mevkilerini muhafaza etmek için cahilleri aldatmaya çalışırlar. Böyle bir cinayet ilahi dinden mahrumiyete, ebedi bir felakete sebeptir. ${ }^{92}$ Burada sözü edilen tahrîf bizzat kitabın lafzında değil sözde vuku bulmaktadır. Yani bu âyette sözü edilen tahrîf şekli manendir.

\section{Nisa 4/46:}

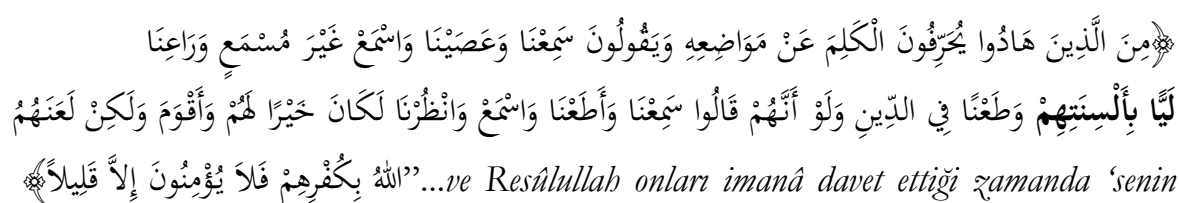
sözünü işittik ve emrine asi olduk ve sen bizden emr-i din hakekenda hic bir kimseden ișitmedig̈in kelami isit ve bize riayet et ki, bizden kelimat-1 ser'iye istifade edesin' derler ve bu sözden ancak lisanlarını dürmek ve sözlerini haktan batıla tabvil etmek ve hakarete benzer söz söylemek ve ebl-i imam teveccüh ettikleri tarik-i haktan çevirmek ve din-i mübine ta'netmek kastederler."

Tahrîfin şekilleri ile ilgili olarak yaptığı açıklamada Elmalılı, Yahûdîlerin sadece kitapta değil, bir söz söyledikleri zaman duydukları ve bildikleri bir kelimeyi bile değiştirerek söylemeleri suretiyle de tahrîf yaptıklarını açıklamaktadır. "Yahûdîler Hz. Peygamber'in huzuruna gelir, bazı şeyler sorarlar, yanından çıktıkları zaman ise O'nun sözlerini değiştirerek yaymaya çalıșırlardı".93 Vehbi Efendi'nin açıklamasına göre Yahûdîlerden bir grubun Resûlullah'a karşı takındıkları tavra değinilmekte ve bu şekilde yaptıkları tahrîf açıklanmaktadır. Resûlullah bir şey emrettiğinde zahirde Lَّ "semi’na"/işittik deyip batında عَصَيْنَ "asayna"/âsî geldik demeleri ortaya koyulmuştur. Bu tavırlarına âyette verilen bir diğer örnek ise: yine Yahûdîlerden bir grubun

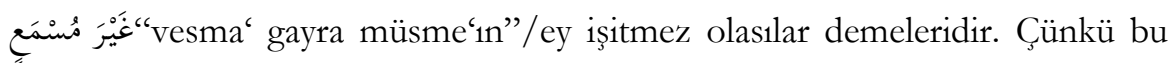
kelimeler övme ve sayg1 ifadeleri olduğu gibi aynı zamanda yermek ve kötü söz ifadeleri de olabilmektedir. Yahûdîler bu kelimeleri Resûlullah'a hakaret ve kötü söz maksadıyla söylediklerinden dolayı Yüce Allah onları uyarmıştır. Bu

92 Bilmen, Tefsîr, I, 401, 402.

93 Elmalılı, Hak Dini Kur'ân Dili, II, 567, 568. 


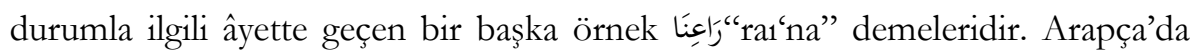
bu kelime "bize riayet et" demekse de Yahûdîler bu kelimeyi alay için kullanmışlardır ki anlamı şu şekilde olmaktadır: "Kulağını bizim sözümüze ver, dinle kelamımızı, sükut et ve söylediğimizi fehmet". Görüldüğü gibi bu anlamda bu söz Resûlullah’a hakaret içermektedir. Âyette geçen "leyyen bi elsinetihim" sözünün anlamı; lisanlarını dürmek ve döndürmek, uygun olan kelime yerine uygun olmayan kelime kullanmak ve metheder gibi kelimeleri kötü söz söylemek maksadıyla kullanmaktır. Yahûdîlerin bu şekilde tahrîf yaptıklarını açıklayan Yüce Allah, onların küfürleri sebebiyle lanetlendiklerini ve iman etmediklerini ancak onlardan az bir kimsenin iman ettiğini âyette vurgulamıştır. ${ }^{94}$

Bilmen'e göre "Yahûdîlerden bazıları, kelimeleri yerlerinden tebdîl ederler ve dillerini eğerek ve dine dokunarak 'işittik ve isyan ettik, işit, işitmez olası ve râın'a derler. Eğer onlar 'işittik ve itaat ettik ve işit ve bize nazar et' deselerdi elbette onlar için hayırlı ve ziyade dürüst olurdu. Lakin Yüce Allah, onlara küfürleri sebebiyle lanet etmiştir. Artık pek az müstesna olmak üzere onlar iman etmezler." Âyetin ilk bölümünde geçen; Yahûdîlerin kelimeleri yerlerinden tebdîl etmeleri meselesi tahrîf bölümünde ele alınmıştı. İkinci bölümünde leyy kelimesi ile ilgili olan kısma gelince; o Yahûdî olanlardan bir grup, meclis-i nebevide ve diğer yerlerde dillerini eğip bükerek, yüz döndürerek ve dine karşı alayda bulunarak Resûlullah'a karşı kötü söze cüret ederek 'işittik ve isyan ettik' derler. Böylece hasetlerini, düşmanlıklarını gösterirler ve 'işit, işitmez olası ve râna derler ki Resûlullah'a hitaben 'sen işit, mekruh olan bir sözü işitmez olduğun halde ve bizlere riayet et' demiş olurlar. Bu söz aynı zamanda 'sen işit, sağırlık veya ölüm sebebiyle asla söz işitmez bir halde olarak' manâsına da gelmektedir. Rânna kelimesine gelince; bu kelime, 'bize riayet ve hürmet et' gibi bir manâyı içerir. Resûlullah'a karşı bu şekilde sözler söylemek ahlaka ve edebe aykırı olmakla beraber Yahûdîlerin bu sözü O'na karşı söylemeleri onların dalaletine açık bir işarettir. ${ }^{95}$

Leyy kelimesiyle alakalı olarak her ne kadar Nisâ 4/46 âyeti Hz. peygamber döneminde O'na ve Kur'ân'a karşı yapılan bir yanlış telaffuzu konu alsa da Âl-i İmrân 3/78 âyeti her türlü tahrîfe imkan vermektedir. Bu da dili eğip bükmekle bazen alay için bazen de kitaptaki bir kelimeyi lafzı en yakın kelimeyle değiştirmek şeklinde olmaktadır. Bir de leyy kelimesinin tebdîl kelimesiyle yakınlığı vardır. Hz. Mûsâ dönemi Yahûdîleri "hıtta" kelimesini tebdîl ederek "hınta" yapmışlar; Hz. Peygamber dönemi Yahûdîleri de "râına"yi dillerini eğip bükerek "râûne" demişler ve başka anlama çekmişlerdir.

94 Vehbi Efendi, Hulâsatü'l-beyân, III, 937, 938.

95 Bilmen, Tefsîr, I, 401, 402; Bilmen, Tefsîr, II, 599. 


\section{Nisyân Kelimesi Etrafında Yapılan Yorumlar}

Nisyân, unutma şeklinde gerçekleşen bir tahriftir. Demek ki bir şeyi unutmak da bozulmalara sebebiyet vermektedir. Bu kelime Kur'ân'da Yahûdîler, Hıristiyanlar ve genel olarak da kafirler için kullanılmıştır.

\section{Maide 5/14:}

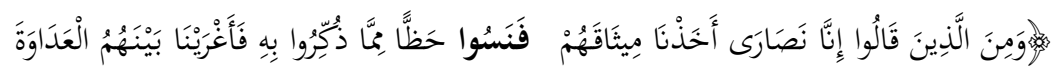

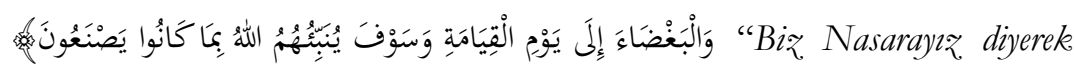

Hiristiyanllk iddia edenlerden din-i Islam'a yardım edeceklerine dair biz abdü misak aldık. $\mathrm{Bu}$ abid üzerine onlar vaaz olunduklar abkamdan nasiplerini unuttular ve kendilerine nazil olan Incil'in abkamm terkettiler..."

Elmalıll, önce İsrailoğulları'nın kalplerinin katıllğı ve bozukluğundan dolayı hatırlatıldıkları ve uyarıldıkları şeylerden en mühim bir kısmını unuttuklarını; yani, hatırlatıldıkları, belletildikleri şeylerin bir kısmından tat almayı, faydalanmayı unuttuklarını, hatırlarına getirmez veya getiremez olduklarını zikretmiştir. Peygamberlerin sonuncusu olan Hz. Peygamber'e iman etmemeleri de bunun bir göstergesidir. Yüce Allah Hıristiyanların da aynı İsrailoğulları gibi yaptığını belirtmiştir. Onlar da İncîl'de açıklandığı üzere Allah'a ve peygamberlerine iman edecekler, Tevrât ve Allah'tan inen diğer kitaplar ile amel edecekler, özellikle de peygamberlerin sonuncusu olan Resûlullah'a da iman edeceklerdi. Fakat çok geçmeden bunlar da sözlerinden, kendilerine anılıp hatırlatılan şeylerden mühim bir kısmını, en çok haz ve nasip alacakları esas noktaları terk edip unuttular, anlaşmalarını bozdular. Bu âyetlerde Yahûdîler ve Hıristiyanlar aynı kategoride değerlendirilmiş, her ikisinin de kitaplarında belirtildiği halde Hz. Peygamber'e iman etmedikleri üzerinde durulmuştur. Bu durumda, onların Hz. Peygamber'in geleceğine ve O'na iman etmeleri gerektiğine dair haberleri kitaplarında tahrîf ettikleri anlaşıllır. Yüce Allah bir sonraki âyetle de (Mâide 15) bunu tafsilatlı olarak açılamaktadır.

Vehbi Efendi, "Yahûdîlerin verdikleri sözden dönmek alıskanlıkları olduğu gibi, Hıristiyanların da verdikleri sözden dönmek ve ahdi bozmak adetleridir" der. Onlar, İncîl'in ahkamıla amel edeceklerine söz vermiş olmalarına rağmen kitaplarının ahkamını Yahûdîler gibi terk ettiler. Zira onlar İncîl'de yer alan Resûlullah'a dair olan hükümleri kabul etmişlerdi. Onlar bu hükümleri terkle, verdikleri sözü unuttular ve onların nasipleri Resûlullah'a iman etmek olduğu halde o nasiplerini arkaya attılar. ${ }^{96}$

Bilmen'e göre, tezkir olundukları şeylerden nasip almayı unutmuş olmaları, Yüce Allah'tan kendilerine emrolunan hükümleri ve özellikle de

96 Vehbi Efendi, Hulâsatü'l-beyân, III, 1176, 1777, 
Resûlullah'a tabi olmayı terk ederek bunlardan faydalı bir nasip almayı, hidayeti terk etmişlerdir. Yüce Allah, İsrâiloğulları'dan ahd aldığı gibi Hıristiyanlardan da ahd aldığını âyette bildirmektedir. Allah'ın birliğini, bütün peygamberleri özellikle de son peygamber Resûlullah'ı tasdik ederek imanda sabit olmaları üzerine İncîl'de kendilerine tenbihte bulunulmuş onlar da buna söz vermişlerdi. Daha sonra İncîl'deki dini emir ve hükümleri tebdîl ve tağyîr etmişler ve ihtar edilmiş oldukları şeylerden nasiplerini unutmuşlardır. İncîl'e muhalif hareketlere cüret etmişler ve bilhassa Resûlullah'ı tasdik etmeleri konusundaki ilahi emri terk etmişlerdir. Kısacası onlar Kitabullah ile ameli terk edip, dini hükümleri tebdîl ve tahrîf etmişlerdir. ${ }^{97}$

\section{A'raf 7/53:}

$$
\begin{aligned}
& \text { لَهَ }
\end{aligned}
$$

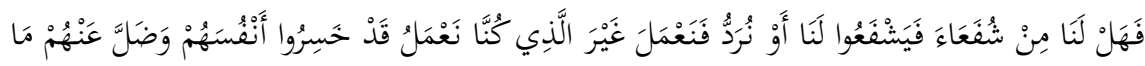

Elmalıl1, burada kıyamet günü kafirlerin gerçekleri görmesiyle karşısındaki Hz. Peygamber'e inanmalarını anlatır. ${ }^{98}$ Vehbi Efendi tefsîrinde, "Resûl-ü kiram, kafirlere, küfür üzere devam etmeleri üzerine ilahi azapla helak olacaklarını ve ahirette azabın her taraflarını kuşatacağını haber verdiğinde kafirler buna inanmadı" der ve şöyle devam eder: Kıyamet günü, Resûlullah'ın vaad ettiği azap gelince Hz. Peygamberi yalanlayan kafirler ikrar ve itiraf ederler ve derler ki: "Resûl-ü kiramın haşr ve neşr, iman ve tasdik, sevap ve ceza gibi bize getirdikleri hükümlerin hepsi haktır. Rabbimizin resûllerinin sözlerinde hilaf yoktur." Bu şekilde söylemekle resûl-ü kiramın hak ve getirdikleri ahkamın doğru olduğunu ikrar ederler. ${ }^{99}$ Bilmen de âyeti şöyle açıklar: $\mathrm{O}$ kafirler $\mathrm{O}$ kitabın açıklamalarının neye varacağını asla beklemezler. Onun doğruluğuna, vaad ve vaidinin gerçekleşeceğine inanmazlar. Fakat onun akıbeti geldiği gün yani onun haber verdiği klyamet vakti geldiğinde onu daha evvel unutmuş olanlar, terk etmiş olanlar diyecekler ki: Muhakkak Rabbimizin peygamberleri hakkı getirmişlerdir. Artık onlar kıyamet gelince uyanacaklar, peygamberlerin onlara bildirmiş olduğu haşr ve neşrin, sevap ve ikabın hak olduğunu anlayıp

97 Bilmen, Tefsîr, II, 741, 742.

98 Elmalıli, Hak Dini Kur'ân Dili, IV, 45.

99 Vehbi Efendi, Hulâsatü'l-beyân, IV, 1642, 1643. 
itirafta bulunacaklar. Fakat artık nedamet vakti geçmiş olduğundan bu itirafları kendilerine bir fayda sağlamayacaktır.

Nisyân kelimesinin ise başta Hıristiyanlar olmak üzere tüm inançsızlar için kullanıldığı görülür. Hıristiyanların ilkleri hak dine inanmışlardır lakin halefleri ise hak dini bırakıp batıl bir dini benimsemişlerdir.

\section{SONUÇ}

Tahrîf kelimesinin müradiflerine bakıldığında ilk olarak akla tebdîl, kitmân, lebs, leyy ve nisyân gelmektedir. Bunlara bir nevi tahrîfin meydana geliş şekli de denilebilir. Kur'ânda bu kelimeler içerisinde en sık kullanılanı kitmân'dır. Kitmân bir şeyin gizlenmesi ve saklanması anlamındadır. Bu kelime de Medine döneminde inen âyetlerde geçmektedir. Bu dönemde Yahûdîlerle yakın ilişkilerde bulunan $\mathrm{Hz}$. Peygamber, onlara da nazil olan âyetleri bildirdiğinde onların yaptı̆̆ iş manevî tahrîf olmuştur. Bu da kutsal kitapta yer alan Hz. Peygamberin sıfatlarını ve kutsal kitabın Kur'ân'la mutabık olan pasajlarını saklayarak yapilır. Lakin kitmânın iki yerde hak ile batılın karıştırılması anlamına gelen lebsden sonra kullanılması manevî tahrîfin yanında lafzî tahrîfin de olabilmesini mümkün kılmaktadır. Lebs kelimesini ise hem anlam hem de lafiz tahrîfi olarak anlamak mümkündür. Tebdîl kelimesi de bir nevi tahrîf çeşidini yani, mevcut kelimenin yerine başka kelimelerin konulmasını karşılar. Lakin bu doğrudan kutsal kitapla ilişkili olmayıp Hz. Mûsâ dönemi Yahûdîlerinin dinî emirlere karşı ciddiyetsizliklerine işaret eder. Bu ciddiyetsizlik doğal olarak kitaplarına da yansiyacaktır. Leyy kelimesi ise Hz. Mûsâ ve dine karşıllk lakaytlığı karşılayan tebdîl kelimesinin $\mathrm{Hz}$. peygamber dönemine yansımasıdır denilebilir. Yani Hz. Mûsâ dönemi İsrailoğulları kelimeyi telaffuzu yakın bir kelimeyle değiştirirken (hıtta'nın/tövbe hınta/buğday olması gibi); Hz. Peygamber döneminde de Arapça râınâ/bizi gözet kelimesi İbranice "ahmak kalın kafalı" anlamına gelen râûne şeklinde anlaşılacak tarzda teleaffuz edilmiştir. Dolayısıyla tarihsel süreç değişse de Ehl-i kitapdan belli bir zümrenin aynı davranışı gösterdiği anlaşılmaktadır.

Kur'ân'da tahrîf kelimesi gibi müradifleri de metinden ziyade muhatap merkeze alınarak kullanılmıştır. Çünkü Kur'ân'da tahrîften ziyade muhatap önemlidir. Muhatap düzgün olunca metin de düzgün kalır. Eğer bir dinî metnin muhatabı normal bir ibadette bile gevşeklik gösteriyorsa dinî metni muhafazada haydi haydi gösterir.

Burada önemli bir ayrıntıda, tahrîf kelimesi sadece Yahûdîler için kullanılırken müradifleri Hıristiyanları da içine almıştır. Yani tahrîf kavramı sadece Yahûdîlerin kutsal kitaplarına karşı olumsuz tavrına hitap ederken eş anlamlıları Ehl-i kitab'nn bütününün olumsuz tavrına işaret eder. Bu yüzden biz 
de birinci makalede daha çok Yahûdî kavramını kullanmayı tercih ederken bu makalede Ehl-i kitap tabirini seçtik.

Son tahlilde müfessirler ve İslâm alimleri, Kutsal kitapların tahrîfi konusunda yargıda bulunurken Kur'ân, sünnet bütünlügünü, kutsal kitap nüshaları arasındaki benzerlik ve farklılıkları, bir de kutsal kitapların mahiyetinin dine uygunluğunu esas almışlardır. İlgili âyetleri tefsîrinde de bu açıcça görülmektedir. Tahrîfi sadece tahrîf ve müradifleri bağlamında değerlendirmek hatalı olacaktır. Çünkü ilgili âyetler kutsal kitaptan ziyade kadim kavimlerin karakterlerini ortaya koymakta ve ümmet-i Muhammed'in benzer davranışlardan uzak durması istenmektedir. Dolayısıyla tahrîf ve eş anlamlıları nihaî sonuç konusunda sağlıklı değerlendirmelere götürmeyecektir. 


\section{KAYNAKÇA}

Kur'ân-1 Kerîm

Kitâb-1 Mukaddes

Adam, Baki, "Kur'ân'ın Anlaşılmasında Tevrât'ın Rolü", İslâmî Araşstrmalar Dergisi, c. 9, sy. 1- 4, Ankara 1996.

Adam, Baki, "Tevrât'in Tahrîfi Meselesine Müslüman ve Yahudi Cephesinden Bir Bakış", Ankara İlabiyat Fakültesi Dergisi, sy. 36, Ankara 1997.

Adam, Baki, Yabudi Kaynaklarna Göre Tevrât, Pınar Yay., İstanbul 2001.

Beydâvî, Nâsiruddîn Ebû Saîd, Envâru't-tenæîl', Dâru ihyâi't-türâsi'l-Arabî, Beyrut 1418.

Biçer, Ramazan, İslâm Kelâmcllarna Göre İncîl, Gelenek Yay., İstanbul 2004.

Cüveynî, Şifäü'l-ğalil, thk. Michel Allard, Dâru'l-meşr1k, Beyrut 1968.

Dihlevî, Şah Veliyyullah, Fevæü'l-kebîr, çev. Mehmet Sofuoğlu, Çağr1 Yay., İstanbul 1980.

Ebussuud Efendi, İrşâdü akli's-selîm, Dâru ihyâi't-türâsi'l-Arabî, Beyrut ts.

Elmalılı, Hak Dini Kur'ân Dili, Azim Dağıtım, İstanbul t.s., I, 327; III, 246.

Gaudeul, J.M. - R. Caspar, "Kitab-1 Mukaddes’in Tahrîfi Konusunda Klasik İslami Kaynakların Yaklaşımı", çev. Ali Erbaş, Sakarya Üniversitesi İlabiyat Fakültesi Dergisi, sy. 7, Sakarya 2003.

Goldziher, Ignaz, "Ehl-i Kitaba Karşı İslâm Polemiği I" çev. Cihad Tunç, Ankara İlahiyat Fakültesi İslâm İlimleri Enstitüsü Dergisi, sy. 4, Ankara 1980.

Goldziher, Ignaz, "Ehl-i Kitaba Karşı İslâm Polemiği II" çev. Cihad Tunç, Ankara İlabiyat Fakültesi İslâm İlimleri Enstituisï Dergisi, sy. 5, Ankara 1982.

Gökkır, Necmeddin, "Kur'ân-1 Kerîm Açısından İlahî Kitapların Tahrîfi Meselesi”, İstanbul Üniversitesi İlahiyat Fakültesi Dergisi, sy. 2, İstanbul 2000.

İbn Aşûr, et-Tabrîr ve't-tenvîr, Dâru'-Tunûsiyye, Tûnus 1984.

İbn Haldun, Kitâbü'l-iber, Dâru'l-kitâbi'l-Lübnânî, Beyrut 1956.

İbn Hazm, Kitâbü'l-fasl, Matbaatü'l-Edebiyye, y.y., .Kahire 1902.

İbn Manzûr, Lisânü'l-Arab, Dâru sâdır, Beyrut 1414. 
İbn Sina, er-Risâletü'l-edhavizyye fi'l-meâd, y.y., 1969.

İİsfehânî, Ragıb, Müfredât, Safvân Adnan, Dâru'l-kalem-ed-Dâru'ş-şamiyye, Dımeşk-Beyrut 1412.

Makrîzî, Ahmed b. Ali, Hitat el-Makrî̀î́, y.y. Kahire 1270.

Mâtürîdî, Ebû Mansur, Te’vîlâtü ebli's-sünne, Müessesetü'r-risâle, Beyrut 2004.

Muhammed Abdüh- Reşid Rızâ, Tefsîru'l-menâr, Dâru'l-ma'rife, Beyrut ts.

Râzî, Fahruddîn, Mefâtîhu'l-ğgayb, Dâru ihyâi’l-türâsi'l-Arabî, Beyrut 1420.

Taberî, Câmiü'l-beyân, Müessesetü'r-risâle, Beyrut 2000.

Tarakçı, Muhammed, "Tevrât ve İncîl'in Tahrîfi ile İlgili Kur'ân Âyetlerinin Anlaşılması Sorunu" Usûl Dergisi, sy. 2, Adapazarı, 2004.

Yavuz, Salih Sabri-Yeniçağ, İbrahim, "Müslüman-Hıristiyan Polemiği Açısından Tahrif”, Milel ve Nihal, cilt 6/sy 1, y. y. Nisan 2006.

Yıldırım, Arif, "Kelamî Açıdan Tevrât ve İncîlde Tahrîf Meselesi", Atatürk Üniversitesi İlahiyat Fakültesi Dergisi, sy. 26, Erzurum 2006.

Zemahşerî, Ebû Kasım Mahmûd b. Ömer, el-Kesşâf an hakâik ğavâmidi't-tenzîl ve'luyûni'l-avâni'l fì vücûbi't-te' 'vîl, Dâru ihyâi't-türâsi'l-Arabî, Beyrut 1997. 